\title{
郊外農業流域におけるリン流出量推定への SWATモデルの適用可能性
}

\author{
清水 裕太 1） 小野寺 真一 1）齋藤 光代 2) \\ 1) 広島大学大学院総合科学研究科 \\ （干739-8521 広島県東広島市鏡山1-7-1） \\ 2) 愛媛大学沿岸環境科学研究センター \\ （テ790-8577 愛媛県松山市文京町2-5）
}

\begin{abstract}
本研究では, リンの負荷量の多い郊外農業流域を対象として, リン流出量の評価に対するSoil Water Assessment Tool（SWAT）モデルによる適用可能性を明らかにすることを目的とし, 流量, SS濃度, 懸濁態および溶存態リン 濃度の再現性の確認とリン流出量の評価を行った. その結果は以下のとおりである. 流量の再現性は, 日流量とし て年間を通じて精度良く再現できた。しかし，高流量時には推定值が過大もしくは過小評価することがあり，その 原因として気象デー夕の時間的および空間的な解像度の影響が示唆された.SS濃度の再現性は米国で開発された経 験的な土砂流出量の推定式による計算であったが，概ね再現することができた。奬濁態リン濃度はSS濃度と同様に 再現することができたことから, 主に土壌浸食によって発生する懸濁態りンの推定については, 適用可能であるこ とが示唆された。ただし, 溶存態リン濃度の再現に関しては, 都市部での推定法に改良の余地があり, 生活排水の 影響が強い流域を対象とする場合に誤差が生まれる可能性が示唆された. 本研究では, 生活排水を強制的にポイン トソースとして考慮させることによって良い再現性を得ることができた．以上のことから，生活排水の影響が強い 流域を対象とする場合には注意が必要であるが, リン流出量の推定に対して, 我が国の郊外農業流域へSWATモデ ルが適用可能であることが明らかとなった。
\end{abstract}

キーワード : リン流出, SWATモデル, 流出解析, 郊外農業流域

\section{I 、はじめに}

リンは生物にとって必要不可欠な元素の一つであ る。一般に自然状態では岩石由来の物質であること から，風化や土壤浸食を経て供給されるため，生物 の利用可能量は限られている (Schlesinger, 1997; Smil, 2000; Mackey and Paytan, 2009).しかしながら， 人間活動, 特に農業活動の増大によって大量のリン が環境中に供給されるようになり，その流出量は地 球全体として最近 150 年間で約 4.7 倍まで増加した (Mackenzie et al., 2002)。この結果, リンの過剩な水 域への負荷が生じ, 富栄養化に伴う赤潮や有害藻類 の発生などの様々な問題を引き起こしている (Smith et al., 1999; Mainstone and Parr, 2002).

また，近年ではリン肥料の原料であるリン鉱石の 枯渴が危惧されている（Steen，1998；西尾，2008； Cordell et al., 2009; Gilbert, 2009) . 特に国内のリン使
用量をすべて輸入に頼っている我が国では, リン成 分の流出抑制に加え効率的利用および再利用が求め られている（黒田ら，2005）。

これらの水環境問題や資源問題の解決のために は, 流域スケールでのリン流出量および空間分布の 評価と共に将来予測を行っていくことが重要である.

我が国では, 水域の富栄養化問題が顕在化した 1970年代を契機に, 各地で河川水中栄養塩濃度の長 期モニタリングが始まり, 栄養塩流出量の評価が進 んできた。しかしながら, 工場排水や生活排水によ る公共用水域の水質污濁が顕著であったため, その 多くが低水時における観測であり, 頻度は多くても 月に一回程度であった。特にリンは土粒子に吸着し やすい性質を持ち，大部分が洪水時に土砂と共に懸 濁態として流出する傾向が確認されていることから (House and Denison, 2002; Withers and Jarvie, 2008), 
リンの流出量を評価するにあたっては, 出水時の流 出を含めて捉えることが重要である.

これまで, 出水時の短期間の詳細な現地観測や畑 地でのライシメータ試験（谷山，2002）が行われ, リン流出に関するプロセスが明らかになってきた。 しかしながら，それらは短時間の事象であることや 多大な労力を伴うことから，全てを把握することは 困難である。そのため, 既存の長期モニタリング デー夕を活用し, 流域内の生物, 化学, 物理過程の 時空間変化を考慮した解析が可能である分布型流出 モデルは,リン流出量の推定にとって有用であると 考えられる，特に我が国では，分布型流出モデルの 解析に必要な長期的な水文水質データや, 土地利用, 土壤などの様々な空間情報が全国規模で整備されて おり，デー夕を容易に入手することが可能であるた め，モデルを用いるための条件は比較的整っている といえる.

一般に, 分布型流出モデルは河川流出量の将来変 動予測, 長期変動要因解析, 過去の流出量復元, 污 染物質の発生源の特定などの目的として使用され, これまでに欧米を中心として数多く開発されてき た。例えば，米国環境保護庁（USEPA）が開発し た河川流量や土砂流出量の再現に重点を置いた Hydrologic Simulation Program-Fortran (HSPF) モデ ル（Johanson et al., 1980）や, 表流水と地下水を連 動させることにより流域内の水収支の解析に重点を 置いたSystéme Hydrologique Européen TRANsport (SHETRAN) モデル (Ewen et al., 2000) やMIKE-SHE モデル (Abbott et al., 1986a, b; Refsgaard and Storm, 1995）などがあり, 近年では, 流量だけでなく水質 や土砂流出量の推定精度も向上してきている (Singh and Frevert, 2006). しかしながら，これまで に開発された分布型流出モデルの多くは, 任意の地 点に対する河川流量や土砂流出量の推定に主眼が置 かれており, 栄養塩流出量を推定する上で重要とな る土地利用やその管理方法とを関連させた解析は困 難であった (Arnold and Fohrer, 2005)。これに対応 可能な分布型流出モデルの一つが, 米国農務省農業 研究局（USDAARS）によって開発された準分布型 物理モデルSoil Water Assessment Tool (SWAT) モ デルである.

SWATモデルは, 農業流域の水, 土砂, 物質の移 流を推定するために特化して作られたモデルであり, 実測デー夕の少ない不特定流域を対象とした流量・ 水質の予測に加え, 農地での作物栽培に関連したパ
ラメー夕, 例えば作物吸収率や肥料の成分, 散布時 期などを考慮した，詳細な土地利用変化による河川 水質への影響のシナリオ解析が可能である (Gassman et al., 2007).このような農業流域に特化 した特徴を持つことや，十分な精度の結果を得られ ること, そして効率的な解析を可能とする GISイン ターフェースやサブソフト群が無償で提供されてい ることもあり，世界各地でこのSWATモデルが適用 されている (Arnold and Fohrer, 2005)。これまでに 欧米を中心とした世界各地でリン流出量推定のため にSWATモデルが適用され, 栄養塩流出の土地利用 変化に対する応答や (Hesse et al., 2008; Cao et al., 2009), リン肥料が湖の富栄養化に与える影響（Bulut and Aksoy, 2008) などについての解析結果が報告さ れている.リンの流出量推定に対する様々なモデル間 の検証に関しては, Nasr et al.(2007)が,SWATモデ ル, HSPFモデルおよびNasr et al. (2005)によって改良 されたSHETRAN / Grid Oriented Phosphorus Component (GOPC) モデルの3つのモデルによる再現性の比較を アイルランドのスケールの異なる3つの平坦な農業流 域にて行い, その結果, リンの日流出量の推定には パラメー夕を細かく設定可能なSWATモデルが最も 良好な出力を示すことを明らかにしている。また， Schoumans and Silgram（2003）は，ヨーロッパの地 形・気候条件が異なる17流域に揖いて農地からの窒 素抢よびリンの流出量の評価のために9つの水文モデ ル (NL-CAT, REALTA, N-LES CAT, MONERIS, TRK, SWAT, EveNFlow, NOPOLU, Source Apportionment) の比較を行っている。その結果, リン流出量の評価 にはNL-CATモデルが最適で, 次点でSWATモデルの 精度が高いとしている。ただしNL-CATモデルは， 5つの小モデルの集合体で形成されているが，統合 パッケージとして提供されておらず，ユーザー自身 がモデルを構築する必要があることや，情報も不足 しているため, 利用するためには高度な専門知識が 必要なこと, そしてヨーロッパ以外での適用例は乏 しいといった問題点がある.SWATモデルは資料が 良く揃って掞り，使用が簡便であることも利点の一 つである。

我が国の流域スケールでのSWATモデルの適用例 としては, 斐伊川を対象とした宍道湖の塩分に及ぼ す気候変動の影響 (Somura et al., 2009a), 網走川か らの土砂流出量 (Somura et al., 2009b) の推定に関 する研究や, 石垣島での土砂流出量の解析事例 （飯泉ら，2009；乃田ら，2009）などがあり，水お 
よび土砂流出についてはある程度の再現性は得られ ている. 森本（2007）は三重県雲出川流域において 水・栄養塩流出量の推定を試みたが, リンの流出量 の推定に対しては十分な再現が得られておらず，懸 濁態リンを考慮する必要性が課題として残されてい る。このようなことからSWATモデルによるリン流 出量の推定に対する我が国での成功例は無い.また, 我が国は大陸の河川と比べて急な河床勾配を持つこ とことから，米国で開発されたSWATモデルを用い てリン流出量の推定を行うためには, モデルの処理 構造やパラメー夕を考慮する必要があると考えられ るが，そのような検討も行われていない。緩やかな 大陸性の河川流域である米国での観測結果に基づい て構築された経験式を用いて我が国のような急勾配 な河川流域で推定するにあたっては，モデルを正し く評価する必要がある。特に, リンの流出はその大 部分が土壇浸食によって発生するため，大陸河川と 比較して我が国のように地形勾配が急な流域におい て評価をする必要がある。また，これまでの事例の 多くは畑地や森林が卓越した単一的な土地利用の流 域が多くを対象としており, 特にリン負荷の高い郊 外に見られる典型的な農地と宅地が混在した流域を 対象に行われた例はほとんどない。一般的に，都市 域の流域では下水道整備が進んでいることが多く, 生活排水は終末処理場からのポイントソースとして 扱うことで対応することができる。一方，山間地や 農村地域の流域では生活排水の影響は相対的に低い ため，それを考慮せずとも良く再現できることもあ る. しかしながら, 都市近郊の流域では, 周辺の農 村地帯がベッドタウンとして造成されていることが 多く，急速に発展したことに起因する排水処理整備 の遅れによって, 都市域や農村地域よりも生活排水 からのリン負荷量は大きいことが考えられる。実測 值には生活排水の影響が含まれてしまっているが, モデルでは現状それを表現することができず，出力 結果が合わないといった問題がある. 以上のように, リン流出量の推定を目的としたSWATモデルの国内 流域への適用可能性に関しては検証が十分でない。

そこで本研究では, リンの流出量の多い都市近郊 農業流域を対象として, リン流出量の評価に対する SWATモデルの適用可能性について明らかにするこ とを目的とする。そのため，1）流量, SS濃度, 溶 存無機態掞よび懸濁態リン濃度の再現性を評価し, 2）SWATモデルの我が国の流域への適用可能性に ついて検証する。解析にはSWATモデルのバージョン

SWAT2005およびesri社製ArcGIS用インターフェース ArcSWAT 2.3.4を使用した.

\section{II. 対象流域}

本研究では広島県東部を流れる一級河川芦田川水 系の支流の一つである高屋川流域を対象とした (図一1)。高屋川は福山市金山（411.2 m) より源を 発し, 途中岡山県を蛇行しながら神辺平野を西流し， 福山市山手町付近で芦田川と合流する流路延長は $24 \mathrm{~km}$, 流域面積は $141 \mathrm{~km}^{2}$ の流域である。山地流域 の地質は主に花崗岩からなり, 平野部では主に山地 から流出した砂や粘土によって構成される沖積平野 が広がっている。また，神辺平野に注ぎ込む支流を 中心に扇状地性の低地をなし, 高屋川本流は典型的 な天井川の形態を示している。そして，河道は人為 的に改修されたところが多く, 流路を直線的に固定 された箇所や堰などの構造物が河道上に多く設けら れている。瀬戸内海気候のため，年間降水量は $1,000 \mathrm{~mm}$ 程度となっている. 芦田川水系は中国地方 の一級河川の中で最もBOD值の高い河川となって おり, 特にその污濁起源のほとんどは, 高屋川流域 に扔ける農業や生活排水などの人間活動由来である （国土交通省河川局，2004）。国土数值情報・土地利 用細分メッシュより集計した1997年の流域土地利用 は, 森林 $57 \%$, 水田 $29 \%$, 畑地8 \%, 市街地6 \% と なっている，人口の急激な増加に伴って土地利用が 著しく変化したことを表しており, 特に水田や畑地

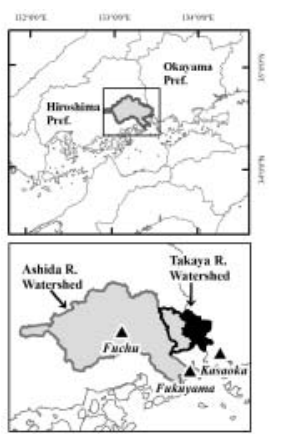

Legend

- Monitoring Station Elevation (m)

- Weather Station

Sircam

- ' Subbasin

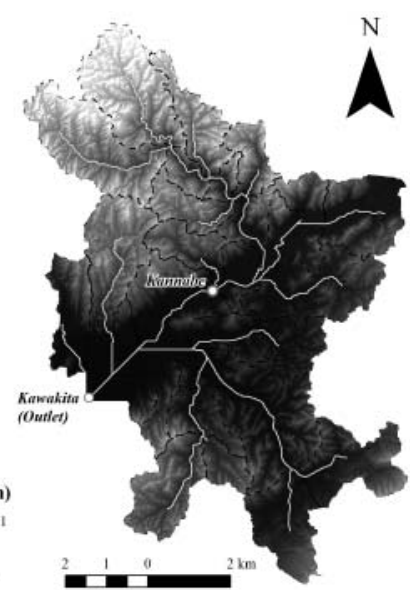

図 -1 対象流域概要

Fig. 1 Study area. 
が減少し宅地へと変化した。また，高屋川流域内の 人口は2006年現在で約 42,000 人であるが，公共下水 道普及率は $17.6 \%$ （2004年現在）と低く，流域内の 多くが単独し尿処理となっている. 高屋川流域の水 質污濁が特に顕著であることから, 改善のために 1996年から芦田川本流の河川水が浄化用水として下 流部に導入され，さらに2001年からは芦田川本流へ の合流直前の地点に河川水のリンを除去する浄化施 設が建設され稼働している.

\section{III.SWATモデルの構造}

\section{1. 流量の推定}

\section{1）地表面流出}

SWATモデルは, Hydrological Response Unit （HRU）と呼ばれる, 土壤の種類や土地利用, 地形 勾配の組み合わせによって細かく分類されたグリッ ドの集合体によって流域を表現しており，それぞれ のグリッド内において水収支や物質収支解析を行い 河川へと流出するように計算する。グリッド内で発 生する流量の計算には1950年代に米国農務省土壤保 全局（Soil Conservation Service; SCS）によって開発 されたCurve Number method（SCS-CN）流出式が使 用されている。これは米国内の郊外のさまざまな小 流域を対象に 20 年間以上の長期間にわたり観測され た膨大な降水量抢よび流出量デー夕から導き出され た関係式であり，次式によって表される（SCS， 1972).

$$
Q_{\text {surf }}=\frac{\left(R_{\text {day }}-I_{a}\right)^{2}}{\left(R_{\text {day }}-I_{a}+S\right)}
$$

ここで， $Q_{\text {surf }}$ は累積流出量 $(\mathrm{mm}), R_{\text {day }}$ は累積降雨 量 $(\mathrm{mm}), I_{a}$ は初期損失量 $(\mathrm{mm}), S$ は最大保留量 $(\mathrm{mm})$ である。 $R_{d a y}>I_{a}$ の時に地表流が発生する。 最大保留量Sは次式によって求めることができる。

$$
S=25.4\left(\frac{1000}{C N}-10\right)
$$

ここで，CNは流出曲線番号である，そして（1）式 および（2）式から，次のように変形することがで きる。

$$
Q_{\text {surf }}=\frac{\left(R_{\text {day }}-0.2 \cdot S\right)^{2}}{\left(R_{\text {day }}+0.8 \cdot S\right)}
$$

ここで, $C N$ は土壤の浸透能や土地利用などの流域 の特徴を表すパラメータであり, 值が高いほど浸透
能が小さく，低いほど大きいことを表す。CNが高 くなると直接流出量は増加する傾向であることが確 認できる。そのため，この式は異なる土地利用や土 壤タイプでも流出量を推定することが可能であり (Rallison and Miller, 1981), 実測データのない流域 や様々な土地利用を持つ流域での流出解析に有効で ある。

ピーク流量は一降雨イベント時の最大流量である. このピーク流量は降雨時の浸食力の指標でもあり, 土畩浸食量を推定するために使用される。 SWATモ デルは改良合理式法 (modified rational method) に よってピーク流量を計算する。合理式法は排水溝や 放水路などの設計のために広く使用されている. 貯 留効果を考慮する必要のない河川でピーク流量が必 要な場合に使用される。

$$
q_{\text {peak }}=\frac{C \cdot i \cdot \text { Area }}{3.6}
$$

ここで, $q_{\text {peak }}$ はピーク流量 $\left(\mathrm{m}^{3} \mathrm{~s}^{-1}\right), C$ は流出係数, $i$ は降雨強度 $\left(\mathrm{mm} \mathrm{hr}^{-1}\right)$, Areaは集水面積 $\left(\mathrm{km}^{2}\right)$ で ある。流出係数 $C$ は次式によって表される。

$$
C=\frac{Q_{\text {surf }}}{R_{\text {day }}}
$$

降雨強度 $i$ は次式によって表される.

$$
i=\frac{R_{t c}}{t_{\text {conc }}}
$$

ここで， $t_{c o n c}$ は小流域の集中時間 $(\mathrm{hr}), R_{t c}$ は集中 時間内に降った雨量の合計 $(\mathrm{mm})$ である。集中時 間とは，ある降雨イベントの時に雨が降り始めてか ら，それが小流域最下流から流出するまでにかか る時間の合計である。 $t_{\text {conc }}$ は次のように表される.

$$
t_{\text {conc }}=t_{o v}+t_{c h}
$$

ここで, $t_{o v}$ は地表流の集中時間 $(\mathrm{hr}), t_{c h}$ は流路の 集中時間 $(\mathrm{hr})$ である.地表流の集中時間 $t_{o v}$ は次式 によって推定される.

$$
t_{o v}=\frac{L_{s l p}}{3600 \cdot v_{o v}}
$$

ここで, $L_{s l p}$ は小流域の傾斜距離 $(\mathrm{m}), v_{o v}$ は地表流 の流速 $\left(\mathrm{m} \mathrm{s}^{-1}\right)$ である. 地表流の流速 $v_{o v}$ はマニング の式から推定される. 


$$
v_{o v}=\frac{q_{o v}^{0.4} \cdot \operatorname{slp}^{0.3}}{n^{0.6}}
$$

ここで， $q_{o v}$ は地表流の平均流量 $\left(\mathrm{m}^{3} \mathrm{~s}^{-1}\right), s l p$ は流 域の平均勾配 $\left(\mathrm{m} \mathrm{m}^{-1}\right), n$ は小流域のマニングの粗 度係数である。また，流路の集中時間 $t_{c h}$ は次式に よって表される。

$$
t_{c h}=\frac{0.62 \cdot L \cdot n^{0.75}}{A r e a^{0.125} \cdot \operatorname{slp}_{c h}^{0.375}}
$$

ここで，Lは小流域内の最下流から最も離れた点か らの距離 $(\mathrm{km}), n$ は流路のマニングの粗度係数, $s l p_{c h}$ は流路内の勾配 $\left(\mathrm{m} \mathrm{m}^{-1}\right)$ である.

時間降水量 $R_{t c}$ はHershfield（1961）に基づいた次 式によって推定される。

$$
R_{t c}=\alpha_{t c} \cdot R_{d a y}
$$

ここで， $\alpha_{t c}$ は日降水量と時間降水量の比である. $\alpha_{t c}$ は次式によって表される.

$$
\alpha_{t c}=1-\exp \left[2 \cdot t_{\text {conc }} \cdot \ln \left(1-\alpha_{0.5}\right)\right]
$$

ここで， $\alpha_{0.5}$ は30分降雨強度である。そして，(5) 式，(6)式，（11）式より（4）式は次のように表さ れる。

$$
q_{\text {peak }}=\frac{\alpha_{t c} \cdot Q_{\text {surf }} \cdot \text { Area }}{3.6 \cdot t_{\text {conc }}}
$$

以上より地表流が見積もられる。

\section{2) 蒸発散}

SWATモデルには最大蒸発散量を推定するための Penman-Monteith法 (Monteith, 1965), Hargreaves and Samani法 (Hargreaves et al., 1985) および Priestley-Taylor法 (Priestley and Taylor, 1972) の3つ の式が選択できる。多くの SWATモデルの適用例で はPenman-Monteith法が使用されているので, 本研 究でも次式で表される同法を用いた.

$$
\lambda E=\frac{\Delta\left(H_{n e t}-G\right)+K_{1}\left(8.64 \times 10^{4}\right) \rho_{a i r} \cdot c_{p}\left[e_{z}^{o}-e_{z}\right] / r_{a}}{\Delta+\gamma\left(1+r_{c} / r_{a}\right)}
$$

ここで, $\lambda E$ は潜熱フラックス密度 $\left(\mathrm{MJ} \mathrm{m}^{-2} \mathrm{~d}^{-1}\right), E$ は蒸発散量 $\left(\mathrm{mm} \mathrm{d}^{-1}\right), \Delta$ は飽和水蒸気圧曲線の傾き $\left(\mathrm{kPa}{ }^{\circ} \mathrm{C}^{-1}\right), H_{n e t}$ は正味放射量 $\left(\mathrm{MJ} \mathrm{m}^{-2} \mathrm{~d}^{-1}\right)$, Gは地面 への熱フラックス密度 $\left(\mathrm{MJ} \mathrm{m}^{-2} \mathrm{~d}^{-1}\right), K_{1}$ は単位変換 係数 $\left(8.64 \times 10^{4}\right), \rho_{\text {air }}$ は空気密度 $\left(\mathrm{kg} \mathrm{m}^{-3}\right), c_{p}$ は定
圧比熱 $\left(\mathrm{MJ} \mathrm{kg}^{-1}{ }^{\circ} \mathrm{C}^{-1}\right), e_{z}^{o}$ は高さ $\mathrm{z}$ における飽和水蒸 気压 $(\mathrm{kPa}), e_{z}$ は高さ $\mathrm{z}$ における水蒸気压 $(\mathrm{kPa}), \gamma$ は乾湿計定数 $\left(\mathrm{kPa}^{\circ} \mathrm{C}^{-1}\right), r_{c}$ は植生群落抵抗 $\left(\mathrm{s} \mathrm{m}^{-1}\right)$, $r_{a}$ は空気拡散抵抗 $\left(\mathrm{s} \mathrm{m}^{-1}\right)$ である.

また, 大気安定度が中立状態かつ風速の対数分布 を仮定できる下での十分に水分を与えられた植物の ためには次式のように書ける（Jensen et al., 1990）:

$$
\lambda E_{t}=\frac{\Delta\left(H_{n e t}-G\right)+\gamma \cdot K_{1}\left(0.622 \lambda \cdot \rho_{a i r} / P\right) \cdot\left(e_{z}^{o}-e_{z}\right) / r_{a}}{\Delta+\gamma\left(1+r_{c} / r_{a}\right)}
$$

ここで, $\lambda$ は蒸発熱 $\left(\mathrm{MJ} \mathrm{kg}^{-1}\right), E_{t}$ は最大蒸散量 $\left(\mathrm{mm} \mathrm{d}^{-1}\right), P$ は大気圧 $(\mathrm{kPa})$ である. 以上より蒸発 散量が見積もられる。

\section{3）浸透}

土畩の種類別に鉛直方向に最大 10 層までの土畩層 を設定し, 各土壤層内に, 土壤層厚, 飽和透水係数, 固場容水量, 土壌浸食係数 $\left(U S L E_{K}\right)$ および粘 土・砂 ・ シルト・磉の重量比の含有率等のパラメー 夕を設定する。そして, 各土壤層において次に示す ように浸透量が計算される。土壤層の水分量が圃場 容水量を超え, その下層の土壤層が飽和していない 時に浸透流が発生する。ただし, 土塞層が凍結して いる時, 浸透流は発生しない. 土壤層内の浸透可能 な水量は次式によって求められる.

$$
S W_{l y, \text { excess }}=S W_{l y}-F C_{l y} \quad\left(S W_{l y}>F C_{l y}\right)
$$

$$
\begin{aligned}
& S W_{l y, \text { excess }}=0 \quad\left(S W_{l y} \leq F C_{l y}\right) \\
& w_{\text {prec }, l y}=S W_{l y, \text { excess }}\left(1-\exp \left[\frac{-\Delta t}{T T_{\text {prec }}}\right]\right)
\end{aligned}
$$

ここで, lyは土畩層, $S W_{l y, \text { excess }}$ は日可能浸透量 $(\mathrm{mm}), S W_{l y}$ は土壤水分量 $(\mathrm{mm}), F C_{l y}$ は固場容水 量 $(\mathrm{mm})$ である。 $w_{\text {prec, ly }}$ は下層土壤への日浸透量 $(\mathrm{mm}), \Delta_{t}$ は計算のタイムステップ当たりの時間間 隔 $(\mathrm{hrs}), T T_{\text {prec }}$ は土壤層を通過する時間 $(\mathrm{hrs})$ で ある. 土壤層を通過する時間 $T T_{\text {prec }}$ は次式によって 表される。

$$
T T_{\text {prec }}=\frac{S A T_{l y}-F C_{l y}}{K_{s a t}}
$$

ここで, SATは土壤飽和水分量 $(\mathrm{mm}), K_{s a t}$ は飽和 
透水係数 $\left(\mathrm{mm} \mathrm{hr}^{-1}\right)$ である. 以上より浸透量が見 積もられる。

\section{4）側方浸透流}

SWATモデルでは側方浸透流をSloan et al.（1983） によって開発されSloan and Moore（1984）によって まとめられた次式のキネマティックストレージモデ ルを用いて計算している.

$$
S W_{l y, \text { excess }}=\frac{1000 \cdot H_{o} \cdot \phi_{d} \cdot L_{h i l l}}{2}
$$

ここで， $H_{o}$ は全ての土畩層の合計の厚さに対する流 出口地点での飽和層の厚さの割合 $\left(\mathrm{mm} \mathrm{mm}^{-1}\right), \phi_{d}$ は間隙率 $\left(\mathrm{mm} \mathrm{mm}^{-1}\right), L_{\text {hill }}$ は傾斜距離 $(\mathrm{m})$ である. （20）式を $H_{0}$ について解くように変形すると次式の ようになる。

$$
H_{o}=\frac{2 \cdot S W_{l y, \text { excess }}}{1000 \cdot \phi_{d} \cdot L_{\text {hill }}}
$$

そして, 側方浸透流量は次のように推定される。

$$
Q_{\text {lat }}=24 \cdot H_{o} \cdot v_{\text {lat }}
$$

ここで， $Q_{\text {lat }}$ は日側方浸透流量 $\left(\mathrm{mm} \mathrm{day}^{-1}\right), v_{\text {lat }}$ は側 方浸透流速 $\left(\mathrm{mm} \mathrm{h}^{-1}\right)$ である.

側方浸透流速 $v_{\text {lat }}$ は次式によって表される.

$$
v_{\text {lat }}=K_{\text {sat }} \cdot \sin \left(\alpha_{\text {hill }}\right)
$$

ここで， $\alpha_{\text {hill }}$ は傾斜角度である。そして, (21) 式, (23)式より（22）式は次式のようになる.

$$
Q_{\text {lat }}=0.024\left[\frac{2 \cdot S W_{\text {ly,excess }} \cdot K_{\text {sat }} \cdot \sin \left(\alpha_{\text {hill }}\right)}{\phi_{d} \cdot L_{\text {hill }}}\right]
$$

そして (24)式により日側方浸透流が見積もられる.

\section{2. リン流出量の推定}

流域へのリンのインプットは, 主に農地への施肥 とポイントソースとしての工場・生活排水である. 前者の場合, 有機態もしくは無機態の肥料として農 地へ散布された後に, 作物吸収の残渣が土畩粒子へ と吸着保持され, 降雨時の地表流発生時に河道へと 流入する構造を持っている. これに対して後者の場 合は, 河道内へ直接流入するという構造になってい る.SWATモデルでは，土壤に含まれるリンは溶存 無機態と有機態を含む懸濁態の 2 種類の形態として 流出するようになっている，土壤中には，無機態リ
ンおよび有機態リンとしてのプールを持っており， 地表から土壤中へ流入したリンは形態別にこれらの プールに蓄積される。無機態リンは安定的，アクティ ブ，溶存態としての3つのプールを持ち，有機態リン は安定的, アクティブ, 残渣としての新鮮な物質の 3つのプールを持っている.

可溶性リン肥料の散布後に溶存リン濃度は土壌中 での反応によって時間と共に急速に減少することが 多くの研究によって明らかとなっている。この初期 の早い反応の後, 溶存リンは初期よりも反応速度は 遅いが減少は数年間続く. 溶存無機態リンの初期の 急速な減少を見積もるために, SWATモデルでは溶 存無機態リンプールとアクティブな無機リンプール の間に急速な平衡が存在すると仮定している. 後続 の遅い反応は, アクティブな無機リンプールと安定 的な無機リンプールの間に遅い平衡が存在するとす る仮定によって計算している。このアルゴリズムは Jones et al. (1984）によって考えられた三つのプー ル間の無機リンの移動を制御している.土壤中の溶 存無機態リンプールとアクティブな無機リンプール の間の平衡はリン利用性指数 (pai) によって支配 される。このpaiは, リン肥料が散布された後に生 じる急速な反応の後に, 溶存無機態となるリン肥料 の割合を規定するパラメータである。これまでの研 究で, このpaiを測定する多くの方法が開発されて きたが, SWATモデルでは Sharpley et al. (1984) の 方法を推薦している。すなわち, 土壤に様々な濃度 の $\mathrm{K}_{2} \mathrm{HPO}_{4}$ を添加し, 橉場容水量まで湿らせた後に, 25 度でゆるやかに乾燥させ, イオン交換水で再度湿 らせる.このサイクルを6か月以上繰り返し, 最後 に陰イオン交換樹脂によって抽出された溶存態リン によって決定される，paiは次式によって計算する ことができる。

$$
\text { pai }=\frac{P_{\text {solution }, f}-P_{\text {solution }, i}}{\text { fert }_{\min P}}
$$

ここで, paiはリン利用性指数, $P_{\text {solution, }, \text { は施肥後の }}$ 急速な反応後の溶存態リンの量 $(\mathrm{g}), P_{\text {solution }, i}$ は施 肥前の溶存態リンの量 $(\mathrm{g}), \mathrm{fert}_{\min P}$ はサンプルに 加えた可溶性リン肥料の量 $(\mathrm{g})$ である.

溶存無機態リンプールとアクティブな無機リン プール間のリンの移動は次の（26）式もしくは （27）式によって制御される. 


$$
\begin{aligned}
P_{\text {sol } \mid a c t, l y}= & P_{\text {solution }, l y}-\min P_{a c t, l y} \cdot\left(\frac{p a i}{1-p a i}\right) \\
& \left(P_{\text {solution }, l y}>\min P_{a c t, l y} \cdot\left(\frac{p a i}{1-p a i}\right)\right)
\end{aligned}
$$

$$
\begin{array}{r}
P_{\text {sol } \mid a c t, l y}=0.1 \cdot\left(P_{\text {solution }, l y}-\min P_{a c t, l y} \cdot\left(\frac{p a i}{1-p a i}\right)\right) \\
\left(P_{\text {solution }, l y}<\min P_{a c t, l y} \cdot\left(\frac{p a i}{1-p a i}\right)\right)
\end{array}
$$

ここで, $P_{\text {sollact,ly }}$ はアクティブな無機リンプールと溶存 無機態リンプール間を移動するリンの量 $\left(\mathrm{kgP} \mathrm{ha}^{-1}\right)$, $P_{\text {solution, ly }}$ は溶存無機態リンの総量 $\left(\mathrm{kgP} \mathrm{ha}{ }^{-1}\right)$, $\min P_{a c t, l y}$ はアクティブな無機リンプール中のリンの 総量 $\left(\mathrm{kgP} \mathrm{ha}{ }^{-1}\right)$ である. $P_{\text {sollact,ly }}$ が正の值を示す時, 溶存無機態リンプールからアクティブな無機リンプー ルへのリンの移動が生じ, 負の值を示す時, その逆の 移動が生じる。ただし，アクティブな無機リンプール から溶存無機態リンプールへの移動速度は, 溶存無 機態リンプールからアクティブな無機リンプールへ移 動する速度の10分の1となる.

また, 安定的な無機リンプールとアクティブな無 機リンプール間のゆるやかな平衡状態を仮定するこ とによって，ゆるやかなリン吸着を計算する。平衡 状態の時, 安定的な無機リンプールはアクティブな 無機リンプールの4倍の大きさになる．また，平衡 状態でないときの両プール間でのリンの移動は次の (28) 式もしくは（29)式によって制御される.

$$
\begin{array}{r}
P_{a c t \mid s t a, l y}=\beta_{e q P}\left(4 \cdot \min P_{a c t, l y}-\min P_{s t a, l y}\right) \\
\left(\min P_{s t a, l y}<4 \cdot \min P_{a c t, l y}\right) \\
P_{a c t \mid s t a, l y}=0.1 \cdot \beta_{e q P}\left(4 \cdot \min P_{a c t, l y}-\min P_{s t a, l y}\right) \\
\left(\min P_{s t a, l y}>4 \cdot \min P_{a c t, l y}\right)
\end{array}
$$

ここで， $P_{a c t s t a, l y}$ はアクティブな無機プールと安定的 な無機プール間を移動するリンの量 $\left(\mathrm{kgP} \mathrm{ha}{ }^{-1}\right)$, $\beta_{e q P}$ はゆるやかな平衡の速度定数 $(0.0006), \min P_{\text {sta,ly }}$ は安定的な無機プール中のリンの総量 $\left(\mathrm{kgP} \mathrm{ha}^{-1}\right)$ で

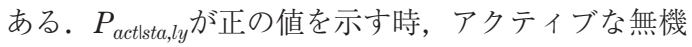
リンプールから安定的な無機リンプールへのリンの 移動が生じ, 負の值を示す時, その逆の移動が生じ る。ただし，安定的な無機リンプールからアクティ ブな無機リンプールへの移動速度は, アクティブな 無機リンプールから安定的な無機リンプールへ移動
する速度の10分の1となる。

全ての土壤層中内の溶存態リン濃度の初期值は $5 \mathrm{mg} \mathrm{kg}$-1 $^{-1}$ 設定されている。この濃度は人間の手が 加わっていない自然状態の濃度を表現しており, 畑 地の表土中の濃度は2 $2 \mathrm{mg} \mathrm{kg}^{-1}$ 程度である (Cope et al., 1981).

アクティブな無機プール中のリン濃度は次式に よって設定される（Jones et al., 1984）.

$$
\min P_{a c t, l y}=P_{\text {solution }, l y} \cdot \frac{1-p a i}{p a i}
$$

安定的な無機プール中のリン濃度は, 次式によっ て設定される (Jones et al., 1984).

$$
\min P_{\text {sta }, l y}=4 \cdot \min P_{\text {act }, l y}
$$

有機態リンは, 腐植土の $\mathrm{N} ： \mathrm{P}$ 比である $8: 10$ 割 合と仮定して設定される。土壤層中の有機態リンの 濃度は次式によって表される。

$$
\operatorname{org} P_{h u m, l y}=0.125 \cdot \operatorname{org} N_{h u m, l y}
$$

ここで, $\operatorname{org} P_{h u m, l y}$ は土壤中の有機態リン濃度 $(\mathrm{mg}$ $\left.\mathrm{kg}^{-1}\right), \operatorname{org} N_{h u m, l y}$ は土壤中の有機態窒素濃度 $\left(\mathrm{mg} \mathrm{kg}^{-1}\right)$ である。

新鮮な有機物プール中のリンの初期值は, 土畩表 層 $10 \mathrm{~mm}$ 中以外の全ての層で0に設定される。土壌 表層 $10 \mathrm{~mm}$ 中の新鮮な有機物プールは, 土㥽表層の 残渣プールの初期值の $0.03 \%$ \%割り当てられる。こ れらは次式によって表される。

$$
\operatorname{org}_{\text {frsh }, \text { surf }}=0.0003 \cdot r s d_{\text {surf }}
$$

ここで, $\operatorname{org} P_{\text {frsh,surf }}$ は土畩表層 $10 \mathrm{~mm}$ 中の新鮮な有 機物プール中のリン $\left(\mathrm{kgP} \mathrm{ha}^{-1}\right), r s d_{\text {surf }}$ は土堙表層 $10 \mathrm{~mm}$ 中の残渣プール中の有機物量 $\left(\mathrm{kg} \mathrm{ha}^{-1}\right)$ である.

SWATモデルでは濃度として入力された栄養塩 は，全ての計算において物質量として計算され，そ れは次式によって表される。

$$
\frac{\operatorname{conc}_{P} \cdot \rho_{b} \cdot \operatorname{depth}_{l y}}{100}=\frac{\mathrm{kgP}}{\mathrm{ha}}
$$

ここで, conc $_{P}$ は，土畩層中のリン濃度 $\left(\mathrm{mg} \mathrm{kg}^{-1}\right.$ ま たは $\mathrm{ppm}), \rho_{b}$ は, 土堙表層 $10 \mathrm{~mm}$ 単位容積重量 $\left(\mathrm{Mg} \mathrm{m}^{-3}\right)$, depth $h_{l y}$ は土壤表層の厚さ $(10 \mathrm{~mm})$ であ る。土壤中でのリンの主な移動は拡散であるが,リ ンは動きにくい性質であるため, SWATモデルでは 溶存態リンを土壇表層 $10 \mathrm{~mm}$ から土壤の第1層への 
移動を次式で表している。

$$
P_{\text {perc }}=\frac{P_{\text {solution }, \text { surf }} \cdot w_{\text {perc }, \text { surf }}}{10 \cdot \rho_{b} \cdot \operatorname{depth} h_{\text {surf }} \cdot k_{d, \text { perc }}}
$$

ここで, $P_{\text {perc }}$ は, 溶存態リンの土壤表層 $10 \mathrm{~mm}$ ら土壤の第1層への移動量 $\left(\mathrm{kgP} \mathrm{ha}^{-1}\right), P_{\text {solution,surf }}$ は, 土壤表層 $10 \mathrm{~mm}$ 中に含まれる溶存態リン量 $\left(\mathrm{kgP} \mathrm{ha}^{-1}\right)$, $w_{\text {perc,surf }}$ は土壤表層 $10 \mathrm{~mm}$ か土壊の第1層への水の 浸透量 $(\mathrm{mm}), \operatorname{depth}_{\text {surf }}$ は土壤表層の厚さ $(10 \mathrm{~mm})$, $k_{d, p e r c}$ はリン浸透係数 $\left(10 \mathrm{~m}^{3} \mathrm{Mg}^{-1}\right)$ である.リン浸 透係数は, 土壤表層 $10 \mathrm{~mm}$ 中のリン濃度と浸透水中 のリン濃度の比である。

懸濁態リンに関しては, 土䁃浸食が発生した際に 河道内へと流入する土壤粒子に無機態リンが吸着し たものと仮定している.SWATモデルでの土壤浸食 の処理は, Wischmeier and Smith（1978）によって 多数の試験結果に基づいて開発された経験式である Universal Soil Loss Equation（USLE）法にピーク流 量を考慮するように改良したModified Universal Soil Loss Equation（MUSLE）法（Williams, 1995）を用 いて土壤浸食や土砂生産量を見積もっている。 MUSLE法による土砂生産量は次式によって表される。

$$
\begin{aligned}
\text { Sed }= & 11.8\left(Q_{\text {surf }} \cdot q_{\text {peak }} \cdot A_{h}\right)^{0.56} \\
& K_{U S L E} \cdot C_{U S L E} \cdot P_{U S L E} \cdot L_{s U S L E} \cdot C_{f}
\end{aligned}
$$

ここで, Sedは計算時間当たりの土砂生産量 $(\mathrm{t}), q_{\text {peak }}$ は ピーク流量 $\left(\mathrm{m}^{3} \mathrm{~s}^{-1}\right), A_{h}$ はHRUの面積 $(\mathrm{ha}), K_{U S L E}$ は 土畩浸食係数, $C_{U S L E}$ は作物係数, $P_{U S L E}$ は土畩保全 係数, $L_{S U S L E}$ は地形係数, $C_{f}$ は土質係数である.

有機態掞よび土壤粒子に吸着された無機態リンは 地表流が発生したときに河道へと輸送される。この 形態のリンはHRUからの土砂流出と関係している. 土砂と同時に輸送される懸濁態リンは, McElroy et al. （1976）によって開発され，Williams and Hann (1978) によって改良された次式を用いて推定される.

$$
\operatorname{sed} P_{\text {surf }}=0.001 \cdot \operatorname{conc}_{\text {sedP }} \cdot \frac{\text { sed }}{A_{h}} \cdot \varepsilon_{P \text { sed }}
$$

ここで, sedP $P_{\text {surf }}$ は地表流によって土壤表層から河 道へ土砂と共に輸送されるリンの総量 $\left(\mathrm{kgP} \mathrm{ha}^{-1}\right)$, $\operatorname{conc}_{\text {sedP }}$ は土壤表層 $10 \mathrm{~mm}$ 中の土壤に吸着したリン 濃度 $\left(\mathrm{gP} \mathrm{t}^{-1}\right)$, sedは解析時間単位の土砂生産量 $(\mathrm{t})$, $\varepsilon_{P s e d}$ リンの濃縮係数である.
また，溶存無機態リンは次式によって表される.

$$
P_{\text {surf }}=\frac{P_{\text {solution }, \text { surf }} \cdot Q_{\text {surf }}}{\rho_{b} \cdot \operatorname{depth} h_{\text {surf }} \cdot k_{d, \text { surf }}}
$$

ここで, $P_{\text {surf }}$ は土壤表層から損失する溶存無機態り ン量 $\left(\mathrm{kgPha}^{-1}\right), P_{\text {solution,surf }}$ は土壤表層 $10 \mathrm{~mm}$ 中に存 在する溶存無機態リン量 $\left(\mathrm{kgP} \mathrm{ha}^{-1}\right), k_{d, \text { surf }}$ は土壤表 層中の溶存無機態リン濃度と地表流中の溶存無機態 リン濃度との比率 $\left(\mathrm{m}^{3} \mathrm{Mg}^{-1}\right)$ である。この式は地 表流が発生した時に土壤表層 $10 \mathrm{~mm}$ 内の土壤水中の 溶存無機態リン濃度との濃度勾配によって地表流の 溶存無機態リン濃度が決定することを表現してい る。すなわち，土壤の表層にリンが多く蓄積してい る農地などで溶存無機態リン濃度は高くなる。また， 浅層地下水から河川へ流出する地下水にも溶存無機 態リンが含まれているが，SWATモデルでは浅層地 下水内のリンの移流・蓄積は考慮されていないた め, シミュレーション期間内は一定の濃度として与 えることによって, 地下水からのリン負荷量として 見積もられる。

\section{3. 河道内モデル}

SWATモデルは河道追跡モデルとして集中型 Kinematic Wave法であるMuskingum River Routing法 (McCarthy, 1938) もしくは Variable Storage Routing 法（Williams，1969）のどちらかを選択することが 可能である。これに関しては多くの解説書があるの で，ここでの説明は割愛する。

河道内へ流入したリンは，USEPAによって開発 された河川水質シミュレーションモデルQUAL2E （Brown and Barnwell, 1987）に受け渡され，水中内 での化学変化や, 植物プランクトンへの同化, 堆積 物内での無機化, 土粒子への吸着, 河床への堆積, 水中への溶脱などのプロセスを経て下流へと流出す る（Neitsch et al., 2005)。まず，土砂流出プロセス について説明する。河道内は基本的に河川流速に応 じて移動量が決定する. 河道内のピーク流速 $v_{c h, p k}$ は次式によって表現される。

$$
v_{c h, p k}=\frac{q_{c h, p k}}{A_{c h}}
$$

ここで, $q_{c h, p k}$ は, ピーク流量 $\left(\mathrm{m}^{3} \mathrm{~s}^{-1}\right), A_{c h}$ は, 河 道断面積 $\left(\mathrm{m}^{2}\right)$ である.

ピーク流量 $q_{c h, p k}$ は次式によって定義される. 


$$
q_{c h, p k}=p r f \cdot q_{c h}
$$

ここで, prfはピーク流出調整係数, $q_{c h}$ は, 平均流 量 $\left(\mathrm{m}^{3} \mathrm{~s}^{-1}\right)$ である.

河道から運搬される最大土砂量は, 次式によって 計算される，

$$
\text { conc }_{s e d, c h, m x}=c_{s p} \cdot v_{c h, p k} \operatorname{spexp}^{\sin }
$$

ここで, $\operatorname{conc}_{\text {sed,ch,mx }}$ は水によって運ばれる土砂の最 大濃度 $\left(\mathrm{t} \mathrm{m}^{-3}\right.$ もしは $\left.\mathrm{kg} \mathrm{l}^{-1}\right), c_{s p}$ および spexpは土 砂流出の経験的係数, $v_{c h, p k}$ は河道内のピーク流速 $\left(\mathrm{m} \mathrm{s}^{-1}\right)$ である。一般的な $c_{s p}$ およびspexpの值はそれ ぞれ 0.01 と 1.5 とされており（Bagnold，1977）， SWATでもこれらの值がデフォルト值に設定されて いる。また, spexpは通常1から2の間の值を取り, 実測の土砂流出の負荷曲線から, もしくはBagnold （1977）のように土砂総流出量に基づいた推定によっ て求めることができる.

水によって運ばれる土砂の最大濃度は, 計算ス テップ開始時の土砂濃度 $\operatorname{con} c_{s e d, c h, i}$ と比較され, $\operatorname{conc}_{\mathrm{sed}, \mathrm{ch}, \mathrm{i}}>\operatorname{con} \mathrm{c}_{\mathrm{sed}, \mathrm{ch}, \mathrm{mx}}$ となった時は, 河道内に余剰 分の土砂が堆積するプロセスとなっている．河道内 への正味の土砂堆積量は, 次式によって表される,

$$
\operatorname{sed}_{\text {dep }}=\left(\text { conc }_{\text {sed }, \text { ch }, i}-\text { conc }_{\text {sed }, c h, m x}\right) \cdot V_{c h}
$$

ここで, $s e d_{d e p}$ は河道内への土砂堆積量 $(\mathrm{t}), V_{c h}$ は, 河道内の水の体積 $\left(\mathrm{m}^{3}\right)$ である. そして, $\operatorname{conc}_{s e d, c h, i}<\operatorname{conc}_{s e d, c h, m x}$ となったとき, 河道内に堆積 した土砂の再懸濁が生じ, 次式によって下流への運 搬が生じる。

$$
\begin{aligned}
\operatorname{sed}_{\text {deg }}= & \left(\text { conc }_{\text {sed }, c h, m x}-\operatorname{conc}_{s e d, c h, i}\right) \cdot V_{c h} \\
& \cdot K_{C H} \cdot C_{C H}
\end{aligned}
$$

ここで, $\operatorname{sed}$ deg は河道内からの土砂移動量 $(\mathrm{t}), K_{C H}$ は河道浸食係数 $\left(\mathrm{cm} \mathrm{hr}^{-1} \mathrm{~Pa}^{-1}\right), C_{C H}$ は河道被覆係数 である。

河道浸食係数 $K_{C H}$ とはUSLE式で使用されている 土壤浸食概念と同様のものであり, Hanson（1990） によって開発された, 浸食に対する河床もしくは河 岸の特性を表すパラメータの一つである。これは, 水中で河床等の対象物に向かって垂直に水流を噴射 した時に浸食された物質量から計算される。この実 験の浸食プロセスの重要な変数は, 噴射イベント中
に除去された物質の体積, 河床から噴射装置までの 高さ, 噴射装置のノズルの直径, 噴射速度, 時間, 流体密度，浸食係数である。ただし，この実験には 手間がかかることから, Hanson（1991）は噴射装置 を使って得られた結果と受食性を関連づける経験的 係数であるジェットインデックス係数 (Ji) を定義 した．Jiは，単位時間および噴射流速当たりの除去 される深さの関数であり, 国際標準化工業規格 (ASTM）D5852-95に概説された手順に従って，最 小二乗法によって求められる。そして, 次式によっ てJiから河道浸食係数を求めることができる.

$$
K_{C H}=0.003 \cdot \exp [385 \cdot J i]
$$

ここで，Jiはジェットインデックス係数である。ま た，植生は河床付近の流速の低下，すなわち浸食力 を低下に影響する。

河道被覆係数 $C_{C H}$ は, この影響を表すパラメータ であり, 無植生の河道での浸食と植生のある河道で の浸食の比によって定義される。

堆積量や再運搬量が計算されると, 河道内の土砂 量の最終的な值が次式によって決定される.

$$
\operatorname{sed}_{c h}=\operatorname{sed}_{c h, i}-\operatorname{sed}_{d e p}+\operatorname{sed}_{d e g}
$$

ここで, $\operatorname{sed}_{c h}$ は河道内の浮遊土砂量 $(\mathrm{t}), \operatorname{sed}_{c h, i}$ は 計算ステップ開始時の河道内の浮遊土砂量 $(\mathrm{t})$ で ある。

そして, 最終的な河道内からの土砂運搬量は次式 によって計算される，

$$
\operatorname{sed}_{\text {out }}=\operatorname{sed}_{c h} \cdot \frac{V_{\text {out }}}{V_{c h}}
$$

ここで, $V_{\text {out }}$ は1計算ステップ中の河道からの水の 流出量 $\left(\mathrm{m}^{3}\right)$ である.

河道内のリンは, 植物プランクトンなどを含んだ 生態系を循環して輸送される。まず，植物プランク トンが枯死すると有機態リンへと恋換される. そし て，有機態リンの一部は無機化プロセスを経て植物 プランクトンが吸収可能な溶存無機態へと変換さ れ, また, 一部は堆積作用によっても河道から除去 される.このプロセスは次式によって定義される。

$$
\begin{aligned}
\Delta o r g P_{s t r}= & \left(\alpha_{2} \rho_{a} \text { algae }-\beta_{P, 4} \text { org } P_{\text {str }}\right. \\
& \left.-\rho_{5} \text { org } P_{\text {str }}\right) T T
\end{aligned}
$$

ここで, $\Delta o r g P_{s t r}$ は有機態リン濃度の変化 $\left(\mathrm{mgP} \mathrm{L}^{-1}\right)$, $\alpha_{2}$ は藻類バイオマス中の含有リン比率 $(\%), \rho_{a}$ は 
藻類の呼吸もしくは死亡率 $\left(\mathrm{day}^{-1} \mathrm{or} \mathrm{hr}^{-1}\right)$, algaeは 藻類バイオマスの初期濃度 $\left(\mathrm{mg} \mathrm{L}^{-1}\right), \beta_{\mathrm{P}, 4}$ は有機態 リンの無機化量 $\left(\right.$ day $^{-1}$ or $\left.\mathrm{hr}^{-1}\right), \operatorname{org} P_{\text {str }}$ は有機態リン の初期濃度 $\left(\mathrm{mg} \mathrm{L}^{-1}\right), \sigma_{5}$ は有機態リンの沈殿量 $\left(\right.$ day $\left.^{-1} \mathrm{or} \mathrm{hr}^{-1}\right), T T$ は河川区間の滞留時間 (day or hr) である。これに対して, 溶存無機態リンは, 有機態 リンの無機化によって放出されるか, 河床堆積物か らの拡散によって供給される。河道内の溶存無機態 リンは，植物プランクトンによる吸収によって減少 する。このプロセスは次式によって定義される.

$$
\begin{aligned}
& \Delta \text { solP } P_{s t r}= \\
& \quad\left(\beta_{P, 4} \cdot \text { org } P_{s t r}+\frac{\rho_{2}}{(1000 \cdot d e p t h)}-\alpha_{2} \cdot \mu_{a} \cdot \text { algae }\right) \cdot T T
\end{aligned}
$$

ここで, $\Delta s o l P_{s t r}$ は溶存無機態リン濃度の変化 $\left(\mathrm{mgP} \mathrm{L}^{-1}\right)$, $\rho_{2}$ は堆積物からの溶存無機態リン供給量 $\left(\mathrm{mgP} \mathrm{m}^{-2}\right.$ day $^{-1}$ or $\left.\mathrm{mgP} \mathrm{m}^{-2} \mathrm{hr}^{-1}\right)$, depthは河道内の水深 $(\mathrm{m}), \mu_{a}$ は 藻類の成長量 $\left(\mathrm{day}^{-1} \mathrm{or} \mathrm{hr}^{-1}\right)$ である.

\section{4. 使用したデータ}

SWATモデルに必要な主な入力デー夕は，流域内 の気象デー夕 (降水量, 気温, 相対湿度, 風速拈よ び日射量）と流域を構成する空間情報デー夕（標高, 土壤, 土地利用）である。気象デー夕については, 高屋川流域に隣接する気象庁アメダス観測所の福 山, 府中, 笠岡, 佐屋気象観測所のデー夕を使用し た（気象庁，2010)。な降水量については，1時間 降水量を使用した。また，日射量については実測值 が存在しないため,（独）農業環境技術研究所が公 開している「モデル結合型作物気象データベース web版」の日平均全天日射量データを使用した（農 業環境技術研究所, 2009). 流域の空間情報につい て, 標高データは国土地理院発行の数值地図 $50 \mathrm{~m}$ メッシュ（標高）を使用した（国土地理院，1979）. 土壤デー夕は国土交通省土地・水資源局国土調査課 の 20 万分の 1 土地分類調査の土壤分類図を使用した (国土交通省土地 - 水資源局国土調査課，2009).土 地利用データは国土交通省の国土数值情報・土地利 用細分メッシュデータ (平成18年度情報) を使用し た(国土交通省・国土計画局総務課国土情報整備室, 2009)。土壤パラメータは, 農業環境技術研究所の 土壤情報閲覧システムから入手した（農業環境技術 研究所, 2011)。また, 流域内の施肥量や散布時期 に関する農業活動情報については，広島県水稲・
麦・大豆栽培基準（広島県，2004）を参考にした。 浅層地下水のリン濃度については, 国土交通省水文 水質データベース（国土交通省河川局，2010）ょり 流域の中流に位置する神辺地下水位 - 水質観測所に おける総リン濃度の平均である $0.037 \mathrm{mg} \mathrm{l}^{-1}$ を使用し た。モデルのキャリブレーション及びヴァリデー ションには，国土交通省水文水質データベース（国 土交通省河川局，2010）より流域の中流に位置する 神辺流量観測所における日流量データと, 川北水質 観測所におけるSS濃度およびリン濃度を使用した (国土交通省河川局, 2010)。本研究では, 溶存性才 ルトリン酸態リン濃度を溶存無機態リン濃度とし て, 総リン濃度から溶存性オルトリン酸態リン濃度 を差し引いたものを懸濁態リン濃度として扱った。 基本的には, SWATモデルのGIS用エクステンショ ンArcSWATを用いて, 対象流域のデータを入力と 解析を行った。なお, 土壤以外のパラメータはデ フォルトの值を使用し, キャリブレーションによっ て調整した。ただし, 高屋川は生活排水の影響が高 いため，生活排水をポイントソースとして本流と支 流が合流する直前の地点に設置した．生活排水のリ ン濃度は, 高屋川で実測したShimizu et al. (2009) の值を使用した。

\section{5. モデル評価法}

本研究は計算の時間間隔を日単位とした。モデル のウォームアップ期間として2000 2001年の 2 年間 を設け，解析期間を2002〜2006年までとし，その内， キャリブレーション期間を2002〜2004年，ヴァリ デーション期間を2005２006年までとした。キャリ ブレーションについては, 流域の水収支, 土砂流出 とリン流出を制御するパラメータに対してLatin Hypercube One-factor-At-a-Time（LH-OAT）法によ る感度分析を行い, 感度の高いパラメータの順位を 決定した。 そして, 水収支については感度が高い上 位10位まで, 土砂拉よびリン濃度については上位4 位までのパラメータについて Shuffled Complex Evolution（SCE）法によって最適值を決定した。ま た, 本研究では水質の再現性の確認に, 月に1度し か測定されていないデー夕を用いている。 そのため, 平水時だけでなく洪水時の流出について十分キャリ ブレーションが行えていない可能性が考えられる. 図一2は神辺水位流量観測所の日流量と川北水質観 測所における2002年から2006年のT-P濃度データと 過去8年間である1994年から2001年までの流量とT-P 
濃度である。この図から，本研究で使用した2002年 から2006年のT-P濃度は, 平水時におけるリンのば らつきと洪水時の流出時を捉えていることがわか る. しかしながら, 流量に関しては最大で $3.24 \mathrm{~m}^{3} \mathrm{~s}^{-1}$ までと必ずしも大きな洪水時を捉えられているとは 言えない。これに対して，モデルで使用した2004年 9月29日に観測されたSS濃度114 $\mathrm{mg} \mathrm{l}^{-1}$ は, 川北水質 観測所における1981年からの観測史上で最も高い濃 度であった。一般に洪水時のリンは懸濁態で占めら れていること, そして懸濁態リンとSS濃度には相 関があることから，T-P濃度の最大值付近を捉えて いると考えることができる。このことから，最大流 量月1度のデータであるものの, 流量および T-P濃 度が幅の広い範囲で得られていると考元, 妥当であ ると判断した. 再現性の評価については, 多くの評 価指標が存在するが (Moriasi et al., 2007), 本研究 では決定係数 $\left(R^{2}\right)$ および次式で表される実測值と 推定值の適合度を表わす指標の一つである Nash Sutcliffe Efficiency $\left(E_{N S}\right)$ を用いた（Nash and Sutcliffe, 1970).

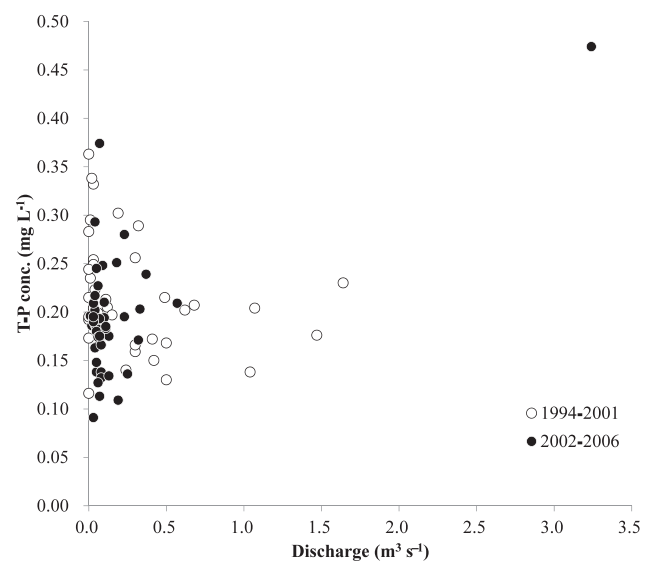

図一2 モデルに使用した流量およびT-P濃度の分布

Fig. 2 Scatter plot of discharge vs. T-P concentration.

$$
E_{N S}=1-\left[\frac{\sum_{i=1}^{n}\left(Y_{i}^{o b s}-Y_{i}^{s i m}\right)^{2}}{\sum_{i=1}^{n}\left(Y_{i}^{o b s}-Y^{\text {mean }}\right)^{2}}\right]
$$

ここで, $Y_{i}^{o b s}$ は, 実測值の流量または濃度， $Y_{i}^{s i m}$ は， モデルによって推定された流量または濃度，Y每的は， 実測值の流量または濃度の平均值である。 $E_{N S}$ は, 1 からーのまでの值を出力し, 1に近いほどモデルの再 現性が高いことを表す。一般に，0から1の間ではそ のモデルの再現性は適用可能な精度であるが，0以下 の場合では非常に悪い再現精度であると認識されて いる (Moriasi et al., 2007).

\section{IV. 結果}

\section{SWATモデルの再現精度の評価}

高屋川の計算範囲は源流から川北水質観測所まで とした。この結果，最終的な流域面積は $121.9 \mathrm{~km}^{2}$ と なった. SWATモデルによって設定された計算範囲 内の土地利用, 表層土壤, 地形勾配を表一1に示す。

流量の再現性については神辺流量観測所地点にお ける日流量に対して，キャリブレーションおよび ヴァリデーションを実施した。この結果，キャリブ レーション期間で $R^{2}=0.95, E_{N S}=0.92$, ヴァリデー ション期間で $R^{2}=0.93, E_{N S}=0.89$ となり, 流量の 再現については全体的に良い精度の結果を得ること ができた (図一3). 次に水質の再現性を確認する. 水質の実測データは月に一度の観測結果しか存在し ないため, 再現性の検証には, 川北水質観測所の水 質データが存在する日を対象にSS濃度，溶存無機 態リン濃度, 懸濁態リン濃度のそれぞれに対して キャリブレーションおよびヴァリデーションを実施 した。

次に懸濁態リンを推定する際に重要となるSS濃度

表-1 流域の土地利用, 土壤, 傾斜の割合

Table 1 Ratio of land use, soil and slope in the watershed.

\begin{tabular}{lr|lr|rr}
\hline \multicolumn{1}{c|}{ Land use } & & \multicolumn{2}{c}{ Soil } & \multicolumn{2}{c}{ Slope } \\
\hline Rice & $18 \%$ & Humic Cambisols & $32 \%$ & $0-1$ & $11 \%$ \\
Agricultural Land-Generic & $7 \%$ & Rhodic Acrisols & $4 \%$ & $1-5$ & $7 \%$ \\
Forest-Mixed & $56 \%$ & Lithosols & $36 \%$ & $5-10$ & $12 \%$ \\
Residential-Med/Low Density & $12 \%$ & Fluvic Gleysol & $18 \%$ & $10-20$ & $61 \%$ \\
Transportation & $3 \%$ & Gleysol & $10 \%$ & $20<$ & \\
Commercial & $3 \%$ & & & & \\
Water & $1 \%$ & & & \\
\hline
\end{tabular}


の再現性について確認を行った.この結果, SS濃度は キャリブレーション期間に $R^{2}=0.88, E_{N S}=0.75$, ヴァ リデーション期間に $R^{2}=0.71, E_{N S}=0.68$ をした (図一 $4 \mathrm{a})$ ，そして, 懸濁態リン濃度はキャリブレーショ ン期間に $R^{2}=0.84, E_{N S}=0.76$, ヴァリデーション期間に $R^{2}=0.67, E_{N S}=0.64$ を示した(図一 $\left.4 \mathrm{~b}\right)$. また, 溶存無 機態リン濃度はキャリブレーション期間に $R^{2}=0.80$, $E_{N S}=0.67$, ヴァリデーション期間に $R^{2}=0.77, E_{N S}=0.49$ を示した (図一 $4 \mathrm{c})$. SS濃度およびリン濃度の再現性の 評価結果は流量と比較して, それほど高い值ではな かった。しかしながら, Moriasi et al. (2007) によ ると $R^{2}$ 值が 0.5 以上であれば比較的再現できていると 認識されている. また, Nasr et al. (2007) が推定を 行ったT-Pの日流出量の再現精度 $R^{2}=0.44 \sim 0.59$ と比 較しても精度良く再現できたといえる。

\section{2. 流域からのリン流出量の推定}

モデルの再現精度は妥当であることが確認された ため, 計算範囲内最下流からのリン流出量の推定を 試みた $($ 図ー5). 総リンとしての年間流出量は, 2002年は437 kg year ${ }^{-1}, 2003$ 年は618 kg year ${ }^{-1}, 2004$ 年は1,492 kg year ${ }^{-1}, 2005$ 年は492 kg year-1 ${ }^{-1}$ 2006年 は1,281 kg year ${ }^{-1}$ となり，年降水量が多い年ほど総り ンの流出量も多くなる傾向であった (図一6). 年間 流出量の内訳としては，懸濁態リンが69７7％の 割合を占めていた.リン流出量の年間変動傾向とし ては，11月頃から4月頃にかけては，大きな流出 イベントは少なく, ゆるやかに流出しているが，5 月頃から10月頃にかけては流出量が多くなる傾向で あった (図一7)。これは，梅雨前線と台風による豪 雨に伴う土砂を含めた懸濁態リンの流出である.

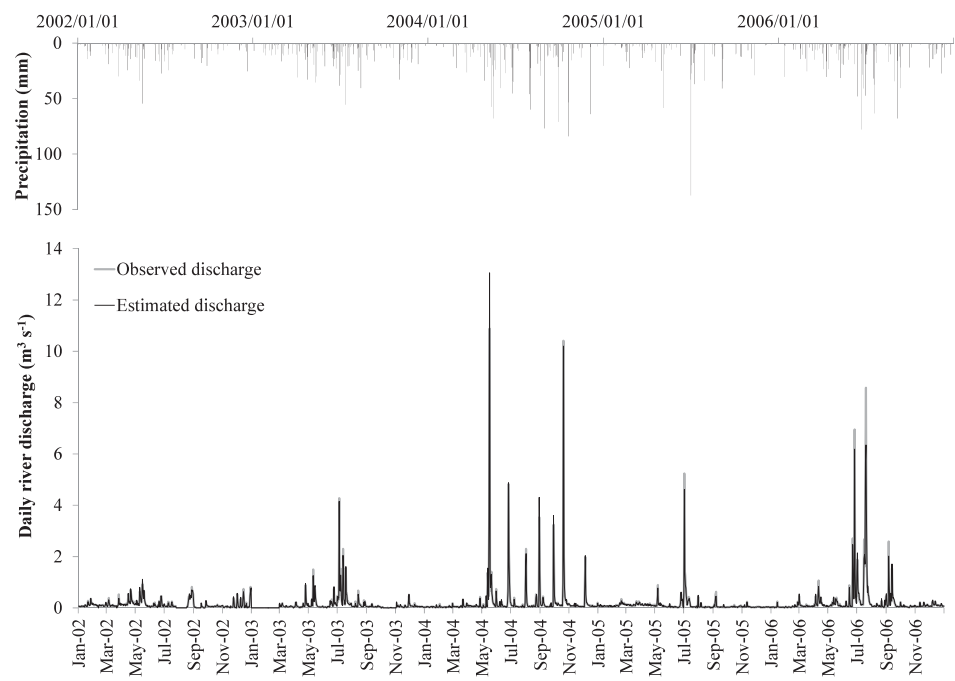

図-3 降水量 $(\mathrm{a})$ と日流量の推定值と実測值の時系列変化 $(\mathrm{b})$

Fig. 3 Daily precipitation (a) and daily discharge (b).
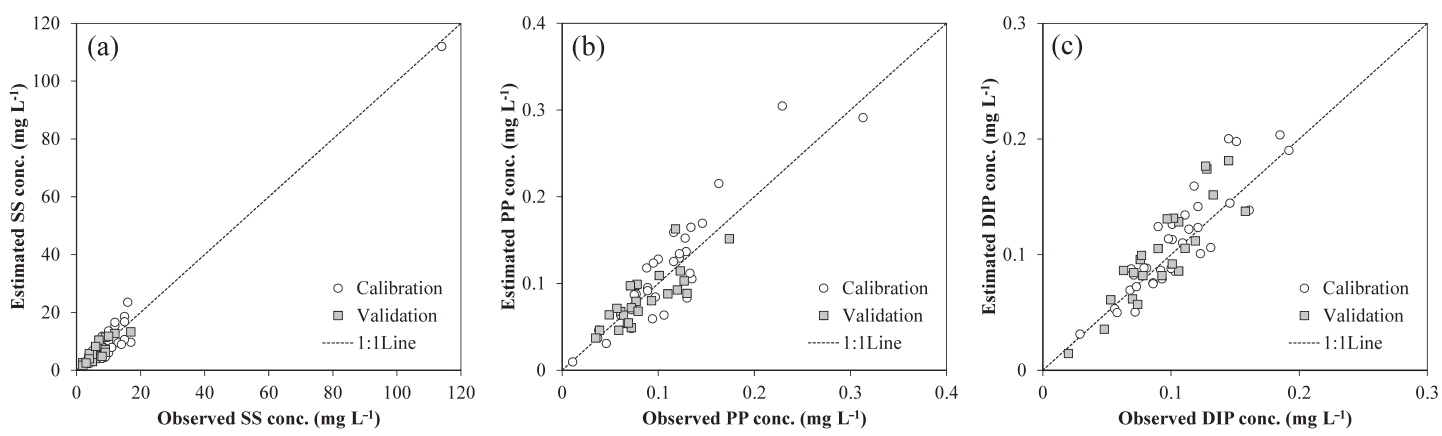

図－4 SSおよびリン濃度の推定值と実測值の関係 $(\mathrm{a}) \mathrm{SS}$ 濃度, (b) 懸濁態リン濃度, (c) 溶存態リン濃度

Fig. 4 Relation between observed and estimated concentrations (a) SS, (b) PP and (c) DIP. 

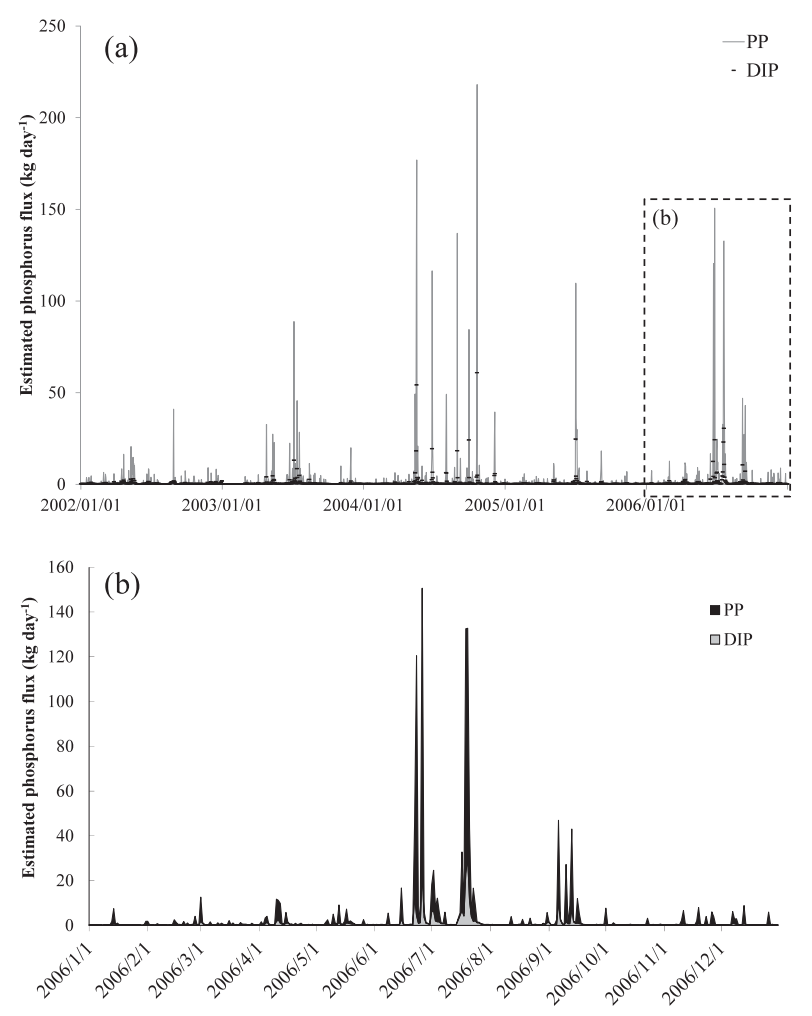

図－5 リン推定流出量の時系列変化（a) 2002-2006（b) 2006

Fig. 5 Estimated daily phosphorus discharge: (a) 2002-2006 and (b) 2006.

2005年7月 2 日は年間懸濁態リン流出量のおよそ6割 が1日で流出し，非常に多くのリンが流出したと 推定された。この日の降水量は福山気象観測所で $137 \mathrm{~mm}$ 記録し，同観測所史上歴代 7位となる豪雨 であった。ただし，年降水量としては2005年は $833 \mathrm{~mm}$ と渴水年であったため, 年流出量は他の年 と比較して少ない. 以上より, リンの流出の多くは 懸濁態であり, 降水量の変動によってリンの流出量 は大きく変動することが確認された。

次に, 流域からのリン供給源の追跡解析を行った。 図一8に2002２006年の小流域別リン年間平均流出 量の空間分布を示す。北部の源流域は流域内で標高 が最も高く地形勾配も急で土砂流出ポテンシャルは 高いものの，ほとんどが森林で覆われているため， 年間 $0.01 \mathrm{~kg} \mathrm{~km}^{-2}$ と流域内では最も少なく, 流域から のリン流出量への寄与は小さいことを示した.一方, 北東部の小流域では平均で年間 $0.56 \mathrm{~kg} \mathrm{~km}^{-2}$ を示し た。この小流域は地形勾配は源流域ほど急ではない が，若干の傾斜とともに畑地が比較的多く分布して いることから，土畩浸食によるリンの流出が発生し
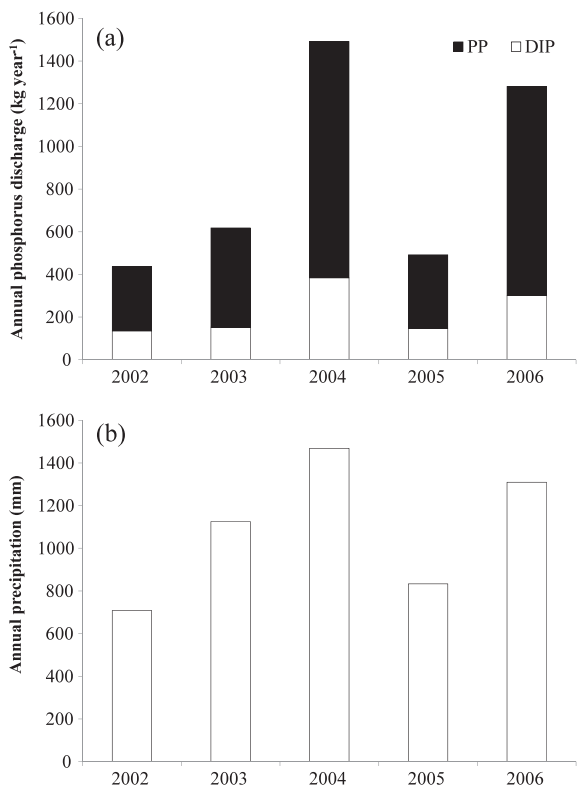

図－6 推定年間リン流出量 $(\mathrm{a})$ と年降水量 $(\mathrm{b})$

Fig. 6 Estimated annual phosphorus discharge (a) and annual precipitation (b). 


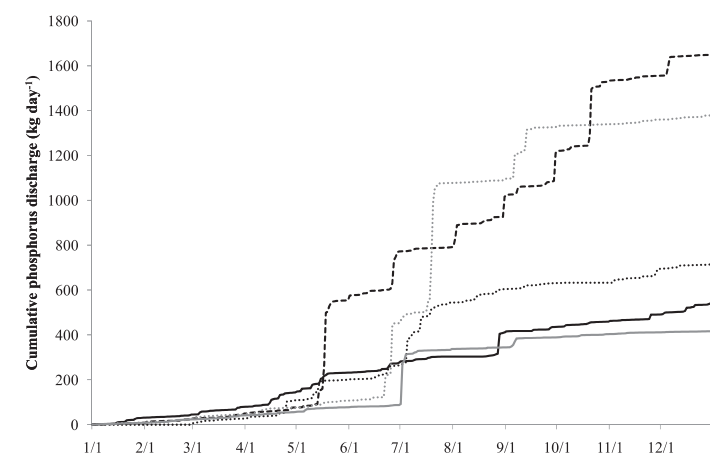

図-7 累積リン推定流出量

Fig. 7 Cumulative estimated daily phosphorus discharge.

ている. 南東部の小流域では平均で年間 $0.36 \mathrm{~kg} \mathrm{~km}^{-2}$ を示した。この上流部では住宅地が多く分布してお り，農地の影響よりは生活排水による影響が強いこ とが確認された。それ以外の本流沿いの低地に位置 する小流域では水田が卓越しており，年間のリン流 出量は $0.1 \sim 0.3 \mathrm{~kg} \mathrm{~km}^{-2}$ の間を示した.

\section{V. 考察}

\section{1. 流量の推定}

流量の再現性は全体的に良好であったが，高流量 時にはモデルが過大もしくは過小評価をする傾向を 示した。流量が, $0.5 \mathrm{~m}^{3} \mathrm{~s}^{-1}$ を超える出水イベント時 にはその傾向が顕著に表れた. 特に，2004年5月17日， 10月20日，2005年7月2日，2006年6月26日，7月20日 は解析期間内では比較的大きな出水イベントであ り，その誤差も大きい。この原因としては, 前線の 活発化によるものや台風の影響による降雨イベント であったが，通常時の降雨と比較して時間的および 空間的に降り方が不均一であったため, 誤差が大き くなった.

図一9は, 日流量の実測値と推定值の累積流量と, その日単位での実測值と推定值の差を表したもので ある。全体的に，実測值を表す実線の折れ線と推定 值を表す点線の折れ線は一致しているが, 出水イベ ント時に大きな差が見られるこれは, 山下ら（2006） が指摘しているように，SCS-CN法は指定タイムス テップ内の降水イベントを単一イベントとして扱う ことと, 降雨強度は一定であるという仮定に基づい ているため, ピーク流量の再現が表現できないとい う問題がある.SWATモデルはサブデイリーの降雨
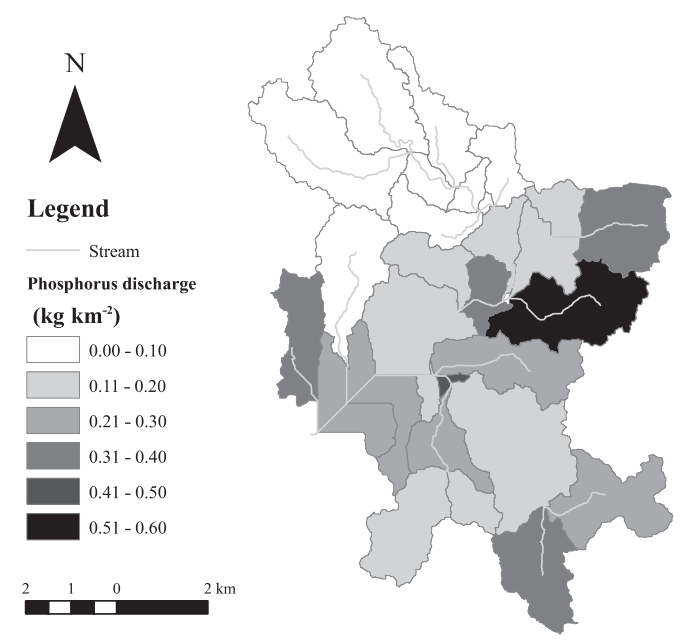

図－8 2002 2006年の小流域別リン年間平均流出量の 空間分布

Fig. 8 Spatial distribution of annual mean phosphorus discharge.

データを考慮することが可能であり，今回は 1 時間 ごとの降水量データを使用したことから，時間的な 不均一性はある程度解決することができ, 全体的に 河川流量は良く再現できている，流域水収支を制御 するパラメータの最終值を表ー2に示す。なお， LH-OAT法による感度分析の結果をもとに最も感度 の高かったパラメータから順位づけをした。水収支 のパラメータについて, 河道内の有効透水係数 CH_Kやマニングの粗度係数 $\mathrm{CH} \_\mathrm{N}$ のパラメータは 通常よりも大きな值を示し, 流域内の土壌の保水容 量SOL_AWCは小さい值を示した. 今回のパラメー 夕は報告されているものと比べて多少の振れが見ら れた（表一3）。前者の場合, 天井川であることから 漏水が生じやすく，また，堰が河道上に多く分布し ていることによって流下を阻害しているため，その 影響を含んでしまっていると考えられる。しかしな がら，これらは流域水収支が合うように最適化され た值であるため, 本研究では河川流量が良く再現で きたことで水収支パラメータの設定を完了とした。 SCS-CN法による流量の推定については, 前述した SWATモデルの我が国の流域へのいくつかの適用例 および本研究においても概ね良好な結果を得られた ことから，日本の流域においても，適用可能である と考えることができる.

\section{2. 土砂流出量の推定}

SWATモデルが土砂流出量を推定するために採用 


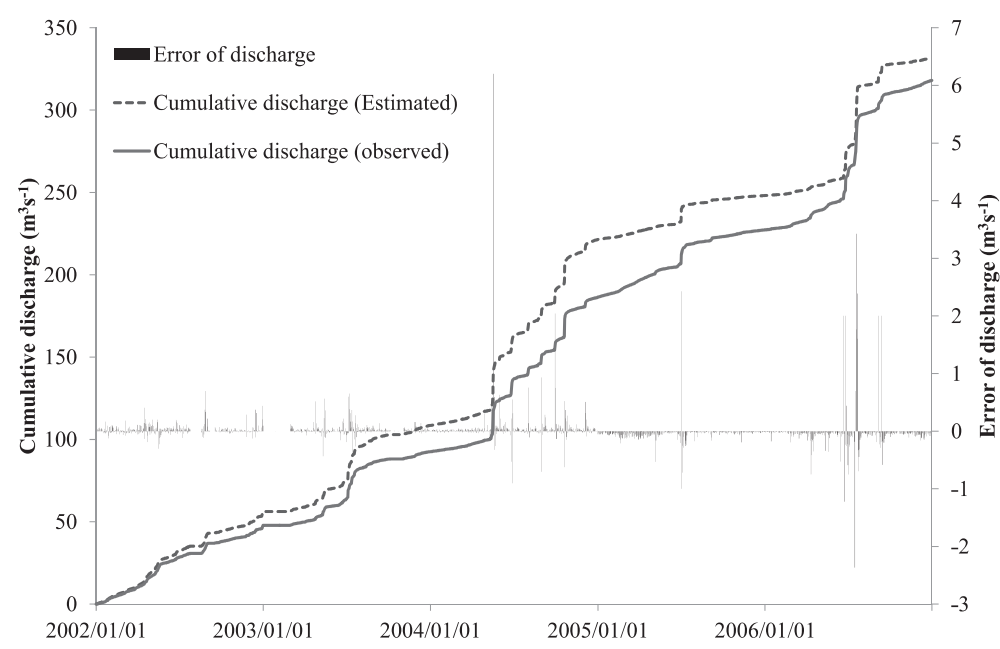

図-9 推定および実測累積流量と推定誤差

Fig. 9 Cumulative discharge and error of estimated discharge.

$$
\text { 表一2 水収支パラメータ }
$$

Table 2 Final calibrated values for water balance.

\begin{tabular}{|c|c|c|c|c|c|}
\hline Ranking & Variable name & $\begin{array}{l}\text { Variable in } \\
\text { equation }\end{array}$ & Definition & $\begin{array}{c}\text { Final } \\
\text { calibrated value }\end{array}$ & File Name \\
\hline 1 & CH_K2 & $K_{c h}$ & $\begin{array}{l}\text { Channel effective hydraulic } \\
\text { conductivity }\left(\mathrm{mm} \mathrm{h}^{-1}\right)\end{array}$ & 81.0 & .rte \\
\hline 2 & SURLAG & surlag & Surface runoff lag time (d) & 1.2 &.$b s n$ \\
\hline 3 & ALPHA_BF & $a_{g w}$ & Baseflow alpha factor (d) & 1.2 &. $\mathrm{gw}$ \\
\hline 4 & $\mathrm{CN} 2$ & $C N 2$ & Initial SCS CN II value & $40-89$ & mgt \\
\hline 5 & CH_N2 & $n$ & Manning's $\mathrm{n}$ value for main channel & 0.3 &.$r t e$ \\
\hline 6 & CANMX & $\operatorname{can}_{m x}$ & Maximum canopy storage (mm) & 7.66 & hru \\
\hline 7 & ESCO & esco & Soil evaporation compensation factor & 0.61 & .bsn, .hru \\
\hline 8 & SOL_AWC & $A W C_{l y}$ & Available water capacity & $0.06-0.09$ & .sol \\
\hline 9 & SOL_K & $K_{\text {sat }}$ & $\begin{array}{l}\qquad\left(\mathrm{mm} \mathrm{mm}^{-1}\right) \\
\text { Saturated hydraulic conductivity }\left(\mathrm{mm} \mathrm{h}^{-1}\right)\end{array}$ & $0.6-154.4$ & sol \\
\hline 10 & BLAI & $L A I_{m x}$ & Maximum potential leaf area index & $0-6$ & crop.dat \\
\hline
\end{tabular}

したMUSLE法について，根幹となったUSLE法は集 水地域の水食による土壤流出量を予測する方法とし て広く用いられているもので，米国では農地保全基 準として採用されてきた。このUSLE法が浸食の駆 動力の一つの指標として降雨を用いているのに対 し, MUSLE法は土壤浸食や土砂生産量を見積もる ために総流量を用いている。我が国へのMUSLE法 の適用例は存在しないが，USLE法を用いた適用例 はいくつかの報告があり，たとえば畑地への適用例 については，土地改良事業計画指針農地開発（改良 山成工）（農林水産省構造改善局計画部，1992）に 詳しくまとめられていることや，畑地土壤だけでな く山林地带 (北原, 2002) や風化花崗岩地带の崩壊
地（小林ら，2004）でも適用できることが確認され ている。特に，実際にSWATモデルを使用して，我 が国の流域での土砂流出量を見積もり，良好な結果 を得られている事例も報告されている (Somura et al., 2009b)。これらを踏まえた上で, 最終的に決定 したパラメータについて, 最も感度が高かった USLE_PとUSLE_Cは水田や山林など土地利用ごと に值が異なった（表一4）.USLE_Cについては，畑 地で 0.4 と最も高く次いで荒地の 0.04 , 水田の 0.03 , 森林の0.001となった. USLE_Pについては, 土地利 用の影響もあるが，主にHRUごとの傾斜によって 変動しており, 北部の源流域の急傾斜のところで 0.52 と高い值を示し, 平野部の傾斜の緩やかなとこ 
表-3 他の流域での水収支パラメータ

Table 3 Water balance parameter in other cases.

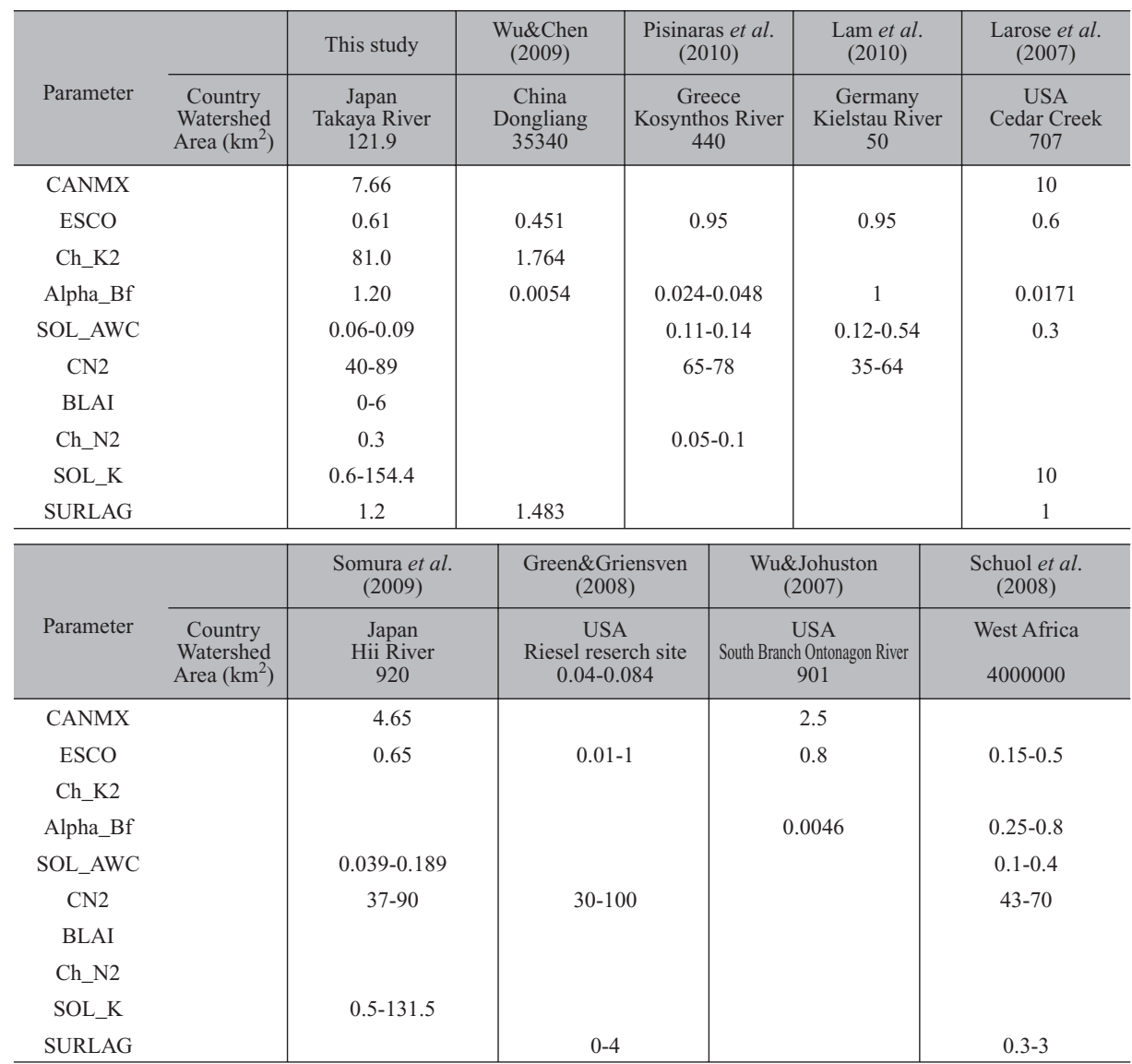

ろで0.3を示した。中国地方を対象にした同様の計 算の報告は無いため，これらの值が妥当であるかは 検証が難しい。しかしながら, 条件が近い四国地域 の中山間地において改良したUSLE式を用いて土壤 浸食量を推定した吉川ら（1998）は，例えば水田田 面のUSLE_Cを0.38,USLE_Pを0.6に, 畑地の USLE_Cを0.05から0.5に, USLE_Pを傾斜に応じて 0.27 から 0.5 まで設定し, 土壤浸食量を正しく算定し ており, 本研究で決定したそれらのパラメータも吉 川ら（1998）の範囲内に分布していることから， USLE式のパラメータは概ね良好であると判断した。 他のパラメータであるSPCONとSPEXPは物理的な パラメータではないため, 本流域に最適化された パラメータと他の事例の值を比較する意味はあまり 無いが，例えばWu and Chen（2009）が中国の Dongliang川流域を対象に解析した例では, SPCON は0.00019, SPEXPは1.488となっており, 今回の值
が特異な值では無い，最後に，CH_COVは土砂が河 道を流下する際に, 植生による堆積のしやすさを表 現しており，0から1に近づくにつれ植生が少なくな る. 対象流域の河道付近には植生が多く繁茂してい ることを確認していることから絶対值は議論できな いものの概ねパラメータの值は合っていると判断し た。また，SS濃度とのヴアリデーションが良好で あることも再現できていることを示すものである が, 実測值のSS濃度は土砂以外のものを含んでい ることがあり, その場合, 実際の土砂流出量と対応 しない. 対象流域ではSS負荷量を土砂流出量と見 なすことができるので（清水・小野寺, 2012), 本 計算結果に扔いては土砂流出量と考えられる. 以上 のことから，主に米国で長年観測された結果を基に 導き出された経験則を柱に持つUSLE法を根幹に持 つ, MUSLE法による土砂流出量の推定は我が国の 流域へ適用可能であると判断した. 
表 4 土砂流出パラメータ

Table 4 Final calibrated values for sediment discharge.

\begin{tabular}{|c|c|c|c|c|c|}
\hline Ranking & Variable name & $\begin{array}{l}\text { Variable in } \\
\text { equation }\end{array}$ & Definition & $\begin{array}{c}\text { Final } \\
\text { calibrated value }\end{array}$ & File Name \\
\hline 1 & USLE_P & P USLE & USLE support practice factor & $0.30-0.52$ & .mgt \\
\hline 2 & USLE_C & C USLE & $\begin{array}{l}\text { Minimum value for cover and } \\
\text { management factor for land cover }\end{array}$ & $0-0.4$ & .mgt \\
\hline 3 & SPCON & $C_{s p}$ & $\begin{array}{l}\text { Linear re-entrainment parameter for } \\
\text { channel sediment routing }\end{array}$ & 0.005 & .bsn \\
\hline 4 & CH_COV & $\mathrm{CCH}$ & Channel cover factor & 0.2 & .rte \\
\hline 5 & SPEXP & spexp & $\begin{array}{l}\text { Exponent re-entrainment parameter } \\
\text { for channel sediment routing }\end{array}$ & 1.2 & .bsn \\
\hline
\end{tabular}

表-5 リン流出パラメータ

Table 5 Final calibrated values for phosphorus discharge.

\begin{tabular}{c|c|c|c|c|c}
\hline Ranking & Variable name & $\begin{array}{c}\text { Variable in } \\
\text { equation }\end{array}$ & Definition & $\begin{array}{c}\text { Final } \\
\text { calibrated value }\end{array}$ & File Name \\
\hline 1 & SOL_LABP & sol_labp & Initial labile P concentration $\left(\mathrm{mg} \mathrm{kg}^{-1}\right)$ & $121-560$ &. $\mathrm{chm}$ \\
2 & PPERCO & $k_{\text {d,perc }}$ & Phosphorus percolation coefficient & 10.0 &. $\mathrm{bsn}$ \\
3 & PHOSKD & $k_{\text {d,surf }}$ & Phosphorus soil partitioning coefficient & 175 &. $\mathrm{bsn}$ \\
4 & RCHRG_DP & $\beta_{\text {deep }}$ & Deep aquifer percolation fraction & $0.1-0.5$ &. $\mathrm{gw}$ \\
\hline
\end{tabular}

\section{3. リン流出量の推定}

最後に, リン流出量の推定に対する適用可能性に ついて検証を行う。リンのパラメータを表一5に示 す.リンのパラメータに関しては，情報が少ないた め検証が難しいが，最も感度の高かったSOL_LABP は谷本ら（2002）の農地での可給態リンの值とほぼ 同様であったことから，良好であると判断した。ま ず，懸濁態リンについては，農地等からの土砂流出 によって導き出された土砂量によって表現されるた め, 土砂流出量が精度良く再現することができれば, 懸濁態リンもまた良く再現できる。溶存無機態リン については，基本的に土畩表層のリン含有量によっ て決定され, 農地や森林等からの発生については地 表流発生時の濃度勾配に依存して流出する。ただし， 不浸透域が広がる都市部ではUSEPAが開発した Storm Water Management Model (SWMM) モデルに 根幹を持つ処理構造となっているため, 別のプロセ スによって制御されており，SWATモデルの都市部 における溶存無機態リン流出量の計算方法はUSGS が開発した経験式に基づく推定法と，不浸透域上へ の蓄積を考慮した速度反応式による流出量の推定法 の二通りの計算方法が用意されている. 都市部の概 念は基本的に無降雨時に不浸透域に蓄積した乾性物 質が，降雨時に洗い流されるというプロセスを想定 しているため, 都市域からの重要なソースである生

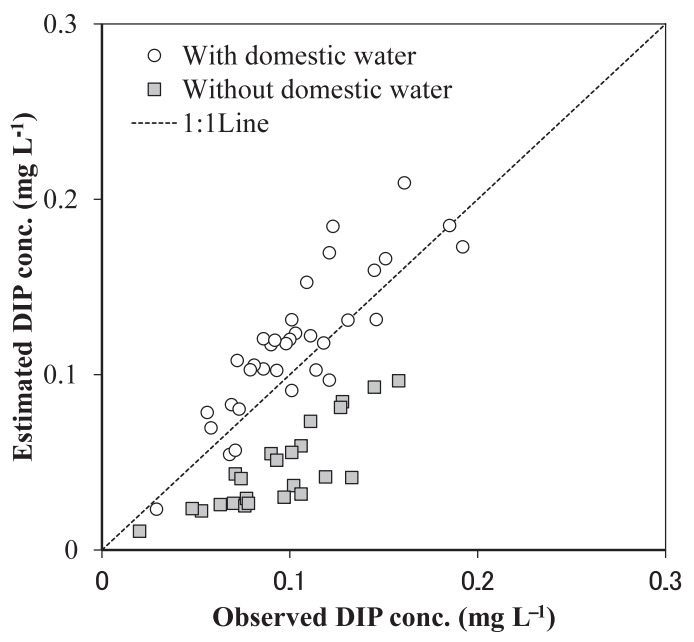

図一10 生活排水を考慮した場合としなかった場合の DIP 濃度の推定值

Fig. 10 Estimated DIP concentration.

活排水, 工業排水のような点源的な流入は考慮され ていない。そのため, 生活排水等の点源の影響が強 い流域を対象とする場合に，その誤差は大きくなる ことが予想される。

これに関して，森本（2007）は生活排水，工業排 水，畜産排水に対して原単位による推定を行い, SWATモデルで見積もられた各小流域からの流出量 
にそれぞれの排水の影響を上乗せして補正してい る. 図一10は, 生活排水を考慮した場合と, しな かった場合のヴァリデーション期間におけるDIP濃 度を示す。この結果から，生活排水を考慮しなかっ た場合は3５割の過小評価が生じてしまった。この ことから, 本研究では, 実測した生活排水濃度を入 力することによって, より高い再現性が得られたと 考えられる。 そのため, 解析対象内に都市部を多く 含む場合には，点源の影響をできるだけ正確に捉え て入力することができれば，SWATモデルはリン流 出量の推定に対して有用なツールになりうる。しか しながら，実際に個々の点源排水を測定している ケースは少なく，また解析範囲が広くなれば難しく なるため, 今後の課題として, 点源排水を簡便に見 積もるための汎用性の高い推定法を構築することが 必要と考えられる。

このように都市部での処理に若干の課題が見られ たが, 我が国の流域への適用に関して, 郊外流域や 農業流域からのリン流出量の推定は精度良く行える ことが確認された。

\section{VI.まとめ}

本研究では, リンの負荷量の多い郊外農業流域を 対象として, 流域スケールでのリン流出量の評価に 対するSWATモデルの適用可能性について明らかに することを目的とし，一級河川芦田川支流の高屋川 流域を対象にリン流出量の再現性と適用可能性の 検証を試みた。その結果, 以下のことが明らかと なった。

1）米国で開発された経験的な流量推定式である SCS-CN法に基づくSWATモデルによる流量の推 定は良く再現することができた。ただし, 出水時 には流量が過大評価または過小評価することが あった。これはSCS-CN法の限界であることが指 摘されているが，全体的な累積誤差は少なく，日 流量を対象とした推定に扔いては良く再現するこ とができた。

2）経験的な土砂流出量の推定式であるUSLE法によ るSS濃度の推定も比較的良く再現することがで きた。懸濁態リン濃度の推定は, 土砂推定式 USLEの結果と関係しており, SS濃度と同じく再 現することができた。主に土壤浸食によって発生 する懸濁態リンの推定については, 我が国の流域 へ適用可能であると考えられる.
3）SWATモデルによる都市部からのリン発生量の 推定法には改良の余地があり, 生活排水の影響が 強い流域を対象とする場合に誤差が生まれる可能 性が示唆された。本研究においては, 溶存態無機 態リン濃度の推定に生活排水をポイントソースと して河道へ設置したため良い再現性を得ることが できた。

4）都市部でのリン流出量推定法に若干の課題が残 されていることが明らかとなったが，全体的にリ ン流出量の推定に対して, 我が国の郊外農業流域 へSWATモデルが適用可能であると考えられる.

\section{謝 辞}

本研究は，科学研究費補助金（基盤研究 $(\mathrm{A})$ ) 「瀬戸内流域から海洋への陸域地下起源物質の不均 一・非定常な流出機構の定量的評価（代表：福岡正 人, $18201007, \mathrm{H} 18-\mathrm{H} 20) 」$, 新たな農林水産政策を 推進する実用技術開発事業「備讃地域陸海域の水 . 栄養塩動態解明と農業への再利用技術の開発（代 表：吉川省子, 1947, H19-21)」, および科学研究費 補助金（基盤研究 (A))「瀬戸内海流域での地下水 流動及び河川作用を考慮したリン循環の解明とその 資源的評価（代表：福岡正人, 21241011, H21-H23)」 の一部である。また，研究を行うにあたり，(独) 国際農林水産業研究センターの飯泉佳子博士ならび に（独）国立環境研究所の林誠二博士，法政大学の 小寺浩二准教授, そして広島大学陸域環境研究会の メンバーには貴重な助言と議論を頂いた。ここに記 して深く感謝の意を表す。

\section{引用文献}

Abbott MB, Bathurst JC, Cunge JA, O'Connell PE, Rasmussen J. 1986a. An introduction to the European Hydrological SystemSysteme Hydrologique Europeen, SHE. 1 History and philosophy of a physically-based distributed modeling system. Journal of Hydrology 87: 45-59. DOI: 10.1016/00221694(86)90114-9.

Abbott MB, Bathurst JC, Cunge JA, O'Connell PE, Rasmussen J. 1986b. An introduction to the European Hydrological SystemSysteme Hydrologique Europeen, SHE. 2 Structure of a physically-based distributed modeling system. Journal of Hydrology 87: 61-77. DOI: 10.1016/0022-1694(86)90115-0.

Arnold JG, Fohrer N. 2005. SWAT2000: current capabilities and research opportunities in applied watershed modelling. Hydrological Process 19: 563-572. DOI: 10.1002/hyp.5611.

Bagnold RA. 1977. Bed load transport in natural rivers. Water Resource Research 13(2): 303-312.

DOI: 10.1029/WR013i002p00303.

Brown LC, Barnwell TO Jr. 1987. The enhanced stream water quality models QUAL2E and QUAL2E-UNCAS documentation and 
user manual. United States Environmental Protection Agency Research Reporting Series EPA/600/3-87/007: 189.

Bulut E, Aksoy A. 2008. Impact of fertilizer usage on phosphorus loads to Lake Uluabat. Desalination 226: 289297. DOI: 10.1016/j.desal.2007.02.112.

Cao W, Bowden BW, Davie T, Fenemor A. 2009. Modelling Impacts of Land Cover Change on Critical Water Resources in the Motueka River Catchment, New Zealand. Water Resources Management 23: 137-151. DOI: 10.1007/s11269008-9268-2.

Cope JT, Evans CE, Williams HC. 1981. Soil test fertility recommendations for Alabama crops. Alabama Agriculture Station Circular No 251; 1-55.

Cordell D, Drangert OJ, White S. 2009. The story of phosphorus: Global food security and food for thought. Global Environmental Change 19: 292-305.

DOI: 10.1016/j.gloenvcha.2008.10.009.

Ewen J. Parkin G. and O'Connell E. P. 2000. SHETRAN: Distributed river basin flow and transport modeling system. Journal of Hydrologic Engineering 5-3: 250-258.

DOI: 10.1061/(ASCE)1084-0699(2000)5:3(250).

Gassman PW, Reyes M, Green CH, Arnold JG. 2005. SWAT peer-reviewed literature: a review. Proceedings of Third International SWAT Conference, 1-18.

Gilbert N. 2009. The Disappearing Nutrient. Nature 461: 716-718. DOI: 10.1038/461716a.

Green $\mathrm{CH}$, Griensven A. 2008. Autocalibration in hydrologic modeling: Using SWAT2005 in small-scale watersheds. Environmental Modelling and Software 23: 422-434.

DOI: 10.1016/j.envsoft.2007.06.002.

Hanson GJ. 1990. Surface erodibility of earthen channels at high stresses. Part II-Developing an in situ testing device. Transaction of the ASAE 33: 132-137.

Hanson GJ. 1991. Development of a jet index method to characterize erosion resistance of soils in earthen spillways. Transaction of the ASAE 34: 2015-2020.

Hargreaves GL, Hargreaves GH, Riley JP. 1985. Agricultural bene.ts for Senegal River Basin. Journal of Irrigation and Drainage Engineering 111(2): 113-124.

DOI: 10.1061/(ASCE)0733-9437(1985)111:2(113).

Hershfield DM. 1961. Rainfall frequency atlas of the United States for durations from 30 minutes to 24 hours and return periods from 1 to 100 years. U.S. Department Commerce Technical Paper 40; $1-61$.

Hesse C, Krysanova V, Pazolt J, Hattermann F. 2008. Ecohydrological modeling in a highly regulated lowland catchment to find measures for improving water quality. Ecological Modelling 218: 135-148.

DOI: 10.1016/j.ecolmodel.2008.06.035.

広島県 2004 : 平成16年度水稲・麦・大豆栽培基準. 86.

House WA, Denison FH. 2002. Total phosphorus content of river sediments in relationship to calcium, iron and organic matter concentrations. The Science of The Total Environment 282283: 341-351. DOI: 10.1016/S0048-9697(01)00923-8.

飯泉佳子・ジェンソンイメリダ・寺園淳子・下田 徹 2009: 石垣島轟 川流域における河川水質・流量特性とSWAT (Soil and Water Assessment Tool)の適用. 日本陸水学会第74回大会講演要旨集, 189.

Jensen ME, Burman RD, Allen RG.(ed) 1990. Evapotranspiration and irrigation water requirements. American Society of Civil
Engineers: New York; 332.

Johanson RC, Imho. JC, Davis HHJr. 1980. User's Manual for Hydrological Simulation Program-FORTRAN (HSPF). United States Environmental Protection Agency Research Reporting Series EPA-600/9-80-015: 678.

Jones CA, Cole CV, Sharpley AN, Williams JR. 1984. A simplified soil and plant phosphorus model. I. Documentation. Soil Science Society America Journal 48: 800-805. DOI: 10.2136/sssaj1984.03615995004800040020x.

気象庁 (2010): “気象統計情報” http://www.jma.go.jp/jma/（参 照: 2010/06/09).

北原 曜 2002 : 植生の表面侵食防止機能. 砂防学会誌 54 (5)： 92-101.

小林由佳・北原矅・小野裕 2004 : 風化花崗岩地帯における崩壊 地の表面侵食とUSLEによるその解析. 日林誌86 (4) : 365-371. 国土交通省河川局 2004: 芦田川河川整備基本方針 94.

国土交通省河川局 2010: “水文水質データベース”

http://www1.river.go.jp/ (参照:2010/06/09).

国土交通省・国土計画局総務課国土情報整備室 2009: “国土数 值情報・土地利用細分メッシュ” http://nlftp.mlit.go.jp/ksj/（参 照:2009/12/01).

国土交通省土地・水資源局国土調査課 2009: “20万分の1土地 分類調査の土壤分類図 (広島県・岡山県) GIS版”

http://tochi.mlit.go.jp/tockok/ (参照: 2009/12/01).

国土地理院 1997 : 数值地図50 mメッシュ(標高) CD-ROM.

黒田章夫・滝口 登・加藤純一・大竹久夫 2005 : リン資源枯渇の危 機予測とそれに対応したリン有効利用技術開発. 環境バイオテ クノロジー学会誌 4 (2)：87-94.

Lam QD, Schmalz B, Fohrer N. 2010. Modelling point and diffuse source pollution of nitrate in a rural lowland catchment using the SWAT model. Agricultural Water Management 97: 317-325. DOI: 10.1016/j.agwat.2009.10.004.

Larose M, Heathman GC, Norton LD, Engel B. 2007. Hydrologic and Atrazine Simulation of the Cedar Creek Watershed Using the SWAT model. Journal of Environmental Quality 36: 521-531. DOI: 10.2134/jeq2006.0154.

Mackey K, Paytan A. 2009. Phosphorus Cycle. Encyclopedia of Microbiology, 322-334.

Mackenzie FT, Ver LM, Lerman A. 2002. Century-scale nitrogen and phosphorus controls of the carbon cycle. Chemical Geology 190: 13-32. DOI: 10.1016/S0009-2541(02)00108-0.

Mainstone CP, Parr W. 2002. Phosphorus in rivers -ecology and management. The Science of The Total Environment 282-283: 25-47. DOI: 10.1016/S0048-9697(01)00937-8.

McCarthy GT. 1938. The unit hydrograph and flood routing. In proceedings of Conference of North Atlantic Division, US Army Corps of Engineers, 608-609.

McElroy AD, Chiu SY, Nebgen JW, Aleti A, Bennett FW. 1976. Loading functions for assessment of water pollution from nonpoint sources. Environmental Protection Technology Series EPA 600/2-76-151: 445

Moriasi DN, Arnold JG, Van Liew MW, Bingner RL, Harmel RD, Veith TL. 2007. Model evaluation guidelines for systematic quantification of accuracy in watershed simulations. Transactions of the Asabe 50(3): 885-900.

Monteith JL. 1965. Evaporation and the environment. In The state and movement of water in living organisms, 19th Symposia of the Society for Experimental Biology. Cambridge University Press, London; 205-234.

森本英嗣 2007 : SWAT (Soil \& Water Assessment Tool) モデルを 
用いた雲出川流域においての水量と污濁負荷量に関する研究. 三重大学大学院生物資源学研究科修士論文; 64

Nasr A, Taskinein A, Bruen M. 2005. Developing an independent, generic, phosphorus modelling component for use with grid-oriented, physically based distributed catchment models. Water Science and Technology 51(3-4): 135-142.

Nasr A, Bruen M, Jordan P, Moles R, Kiely G, Byrne P. 2007. A comparison of SWAT, HSPF and SHETRAN/GOPC for modeling phosphorus export from three catchment in Ireland. Water Research 41: 1065-1073.

DOI: 10.1016/j.watres.2006.11.026.

Nash JE, Sutcliffe JV. 1970. River flow forecasting through conceptual models. Part I -A discussion of principles. Journal of Hydrology. 10(3): 282-290.

DOI: 10.1016/0022-1694(70)90255-6.

Neitsch SL, Arnold JG, Kiniry JR, Srinivasan R, Williams JR. 2005. Soil and Water Assessment Tool. User's Manual Version 2005. Grassland, Soil and Water Research Laboratory, Agricultural Research Service: Texas; 476.

西尾道徳 2008 : “環境保全型農業レポートNo.112望まれるリン の循環利用”, ルーラル電子図書館, 2008/09/16, http://lib.ruralnet.or.jp/libnews/nishio/nishio112.htm. (参照 : 2010/05/08).

乃田啓吾・大澤和敏・飯泉佳子・小沢 聖 2009: 亜熱帯島嶼地域 における水・土砂・栄養塩流出モデル (SWAT) の適用一石垣島 轟川流域を対象として一. 平成21年度農業農村工学会大会講演 会講演プログラム集, 294-295.

農業環境技術研究所 2009: “モデル結合型作物気象データベー ス (MeteoCrop DB)”, ルーラル電子図書館, 2009/09/17, http://meteocrop.dc.a.rc.go.jp/ (参照:2010/06/21).

農業環境技術研究所 2011: “土䁃情報閲覧システム”, http://agrimesh.dc.a.rc.go.jp/soil db/ (参照：2011/05/20).

農林水産省構造改善局計画部 1992: 土地改良事業計画指針農 地開発 (改良山成畑工) 平成4年5月, 191.

Pisinaras V, Petalas C, Gikas GD, Gemitzi A, Tsihrintzis A. 2010. Hydrological and water quality modeling in a mediumsized basin using the Soil and Water Assessment Tool (SWAT). Desalination 250: 274-286.

DOI: 10.1016/j.desal.2009.09.044.

Priestley CHB, Taylor RJ. 1972. On the assessment of surface heat flux and evaporation using large-scale parameters. Monthly Weather Review 100: 81-92.

Rallison RE, Miller N. 1981. Past, present and future SCS runoff procedure. In Rainfall runoff relationship, V.P. Singh (ed). Water Resource Publication, Littleton, CO8; 353-364.

Refsgaard CJ, Storm B. 1995. MIKE SHE In: P.C. Miller, Editor. Computer Models of Catchment Hydrology. Water Resources Publications: Colorado; 809-846.

Schlesinger HW. 1997. Biogeochemistry. Second Edition: An Analysis of Global Change. Aca-demic Press: California; 588. Schoumans OF, Silgram M. (eds.) 2003. Review and literature evaluation of nutrient quantification tools. EUROHARP Report 12003, 120.

Schuol J, Abbaspour KC, Srinivasan R, Yang H. 2008. Estimation of freshwater availability in the West African subcontinent using the SWAT hydrologic model. Journal of Hydrology 352: 30-49. DOI: 10.1016/j.jhydrol.2007.12.025.

Sharpley AN, Gray C, Jones CA, Cole CV. 1984. A simplified soil and plant phosphorus model. II. Prediction of labile, organic, and sorbed P amounts. Soil Science Society America Journal 48: 805-809.

清水裕太・小野寺真一 2012 : 郊外農業流域での栄養塩流出に及ぼ す気候変動の影響. 陸水学雑誌 73:235-254.

Shimizu Y, Onodera S, Saito M, Hirayama Y, Takahashi H. 2009. Dissolved nitrogen removal in the ponded streams of an alluvial, suburban basin with a developing city, western Japan. IAHS Publication 330: 143-149.

Singh VP, Frevert DK. 2006. Watershed Models. Taylor \& Francis, CRC Press; 653.

Sloan PG, Moore ID, Coltharp GB, Eigel JD. 1983. Modeling surface and subsurface stormflow on steeply-sloping forested watersheds. Water Resources Institute Research Report University of Kentucky 142: 167.

Sloan PG, Moore ID. 1984. Modeling subsurface stormflow on steeply sloping forested watersheds. Water Resources Research 20(12): 1815-1822.

DOI: 10.1029/WR020i012p01815.

Smith VH, Tilman GD, Nekola JC. 1999. Eutrophication: impact of excess nutrient inputs on freshwater, marine, and terrestrial ecosystems. Environmental Pollution 100: 179-196.

DOI: 10.1016/S0269-7491(99)00091-3.

Smil V. 2000. Phosphorus in the Environment: Natural Flows and Human Interferences. Annual Review of Energy and the Environment 25: 53-88.

DOI: 10.1146/annurev.energy.25.1.53.

Soil Conservation Service. 1972. Section 4: Hydrology. In National Engineering Handbook, United States Department of Agriculture Soil Conservation Service: Washington; 694.

Somura H, Arnold J, Takeda I, Mori Y, Luzio M. 2009a. Impact of climate change on the Hii River basin and salinity in Lake Shinji: a case study using the SWAT model and a regression curve. Hydrological Processes 23(3): 1887-1900.

DOI: 10.1002/hyp.7321.

Somura H, Takeda I, Mori Y. 2009b. Sensitivity analyses of hydrologic and suspended sediment discharge in the Abashiri River Basin, Hokkaido Region, Japan. International Agricultural Engineering Journal 18(1-2): 27-39.

Steen I. 1998. Phosphorus availability in the 21st Century: management of a non-renewable resource. Phosphorus and Potassium 217: 25-31.

谷本俊明·宮地勝正・松浦謙吉 $\cdot$ 中沢征三郎 - 上本 哲 - 小松武治 2002 : 広島県における農耕地土壤の実態と变化. 広島県立農業 技術センター研究報告 $72: 55-70$.

谷山一郎 2002: 農林地からの土砂流出に伴うリン流出量をモニ タリングする, 環境負荷を予測するーモニタリングからモデリン グヘ一(長谷川周一・波多野隆介・岡崎正規編), 博友社 ; 127142.

Williams JR. 1969. Flood routing with variable travel time or variable storage coefficients. Transactions of the ASAE 12(1): 100-103.

Williams JR. 1995. Chapter 25: The EPIC model. In Computer models of watershed hydrology, Singh VP (ed). Water Resources Publications; 909-1000.

Williams JR, Hann RW. 1978. Optimal operation of large agricultural watershed with water quality constraints. Texas Water Resources Institute Technical Report 96: 152.

Wischmeier WH, Smith DD. 1978. Predicting rainfall erosion losses: a guide to conservation planning (Agriculture Handbook 537). United States Department of Agriculture: 
Maryland; 58.

Withers $\mathrm{P}$, Jarvie H. 2008. Delivery and cycling of phosphorus in rivers: A review. Science of The Total Environment 400: 379395. DOI: 10.1016/j.scitotenv.2008.08.002.

Wu K, Johnston CA. 2007. Hydrologic response to climatic variability in a Great Lakes Watershed: A case study with the SWAT model. Journal of Hydrology 337: 187-199. DOI: 10.1016/j.jhydrol.2007.01.030.

Wu Y, Chen J. 2009. Simulation of nitrogen and phosphorus loads in the Dongjiang River basin in South China using
SWAT. Frontiers of Earth Science in China 3: 273-278. DOI: $10.1007 / \mathrm{s} 11707-009-0032-6$.

山下三男・市川 新・佐藤冬樹・柴田英昭 2006 : 河川水文シミュ レーションモデルの現状と新しい提案.陸水学雑誌 $67: 267-$ 280.

吉川 (遅澤) 省子・山本 博・石原 䀘・花野義雄 1998 : 四国地域に おける農地管理の粗放化に伴う土壤侵食の変動評価. 日本土壤 肥料学雑誌 $69: 265-277$.

（受付：2012年6月18日，受理：2013年2月1日）

\title{
Applicability of SWAT Model for Estimation of Phosphorus Discharge in a Suburban Catchment
}

\author{
Yuta SHIMIZU 1) Shin-ichi ONODERA ${ }^{1)} \quad$ Mitsuyo SAITO ${ }^{2)}$ \\ 1) Graduate School of Integrated Arts and Sciences, Hiroshima University \\ (1-7-1, Kagamiyama, Higashi-hiroshima, Hiroshima, 739-8521, Japan) \\ 2) Center for Marine Environmental Studies, Ehime University \\ (2-5, Bunkyo-cho, Matsuyama, Ehime, 790-8577, Japan)
}

\begin{abstract}
To evaluate the applicability of the Soil Water Assessment Tool model (SWAT) for estima-tion of phosphorus load from a suburban catchment, we examined the reproducibility of river discharge, suspended solids (SS), particulate phosphorus (PP) and dissolved inorganic phos-phorus (DIP) concentrations. Results can be summarized as follows. First, the reproducibility of daily river discharge was good throughout the year, although it tended to be overestimated or underestimated in high discharge periods. This result implies that the reproducibility of discharge is a.ected by spatial and temporal resolution of weather data. Secondly, the repro-ducibility of SS concentration shows acceptable results despite empirical equations developed in the United States of America. Reproducibility of PP concentration was also acceptable as well as SS. Therefore, the model was capable of estimating PP caused by soil erosion. Never-theless, results showed that estimation methods used for DIP in urban areas are not fit for use in Japan. The possibility exists of making an error of estimation of DIP in a watershed that is highly in.uenced by domestic wastewater. In this study, the estimation of DIP was improved by considering domestic wastewater as a point source. Consequently, results con.rmed that SWAT is capable of estimating phosphorus discharge. However, results suggest that the model should be used carefully for DIP estimation in urban areas. Furthermore, results underscore the necessity of improving DIP estimation methods.
\end{abstract}

Key words : phosphorus discharge, Soil Water Assessment Tool, runoff analysis, suburban catchment 